\title{
Results of Work of the Raptor Ringing Center of the Russian Raptor Research and Conservation Network in 2015
}

\section{РЕЗУЛЬТАТЫ РАБОТЫ ЦЕНТРА КОЛЬЦЕВАНИЯ ХИЩНЫХ ПТИЦ РОССИЙСКОЙ СЕТИ ИЗУЧЕНИЯ И ОХРАНЫ ПЕРНАТЫХ ХИщНИКОВ в 2015 гОДУ}

\author{
Bekmansurov R.H. (Elabuga Institute, Kazan Federal University; NP "Nizhnyaya Kama", \\ Elabuga, Republic of Tatarstan, Russia), \\ Karyakin I.V. (Center of Field Studies, N.Novgorod, Russia), \\ Babushkin M.V. (Darwin State Nature Biosphere Reserve, Cherepovets, Russia), \\ Vazhov S.V. (The Shukshin Altai State Academy of Education, Biysk, Russia), \\ Levashkin A.P. (Architectural and Ethnographic Museum-Reserve "Schelkovskiy Hutor", \\ N.Novgorod, Russia), \\ Pimenov V.N. (Nature Park "Volgo-Ahtubinskaya poyma", Volgograd district, Russia), \\ Pchelintsev V.G. (Saint-Petersburg State University, Saint-Petersburg, Russia)
}

Бекмансуров P.X. (Елабужский институт Казанского федерального университета; национальный парк «Нижняя Кама», Елабуга, Республика Татарстан, Россия),

Карякин И.В. (Центр полевых исследований, Н.Новгород, Россия),

Бабушкин М.В. (Дарвинский государственный природный биосферный

заповедник, Череповец, Россия),

Важов С.В. (Алтайская государственная академия образования им. В.М. Шукшина, Бийск, Россия),

Левашкин А.П. (Архитектурно-этнографический музей-заповедник «Щёлковский

хутор», Нижний Новгород, Россия),

Пименов В.Н. (Природный парк «Волго-Ахтубинская пойма», Средняя Ахтуба, Волгоградская область, Россия),

Пчелинцев В.Г. (Санкт-Петербургский государственный университет, Санкт-

Петербург, Россия)

\section{Контакт:}

Ринур Бекмансуров, Елабужский институт Казанского федераль ного университета; Национаиьный парк "Нижняя Кама", 423607, Россия, Республика Татарстан, г. Елабуга, ул. Казанская, 89, тел.: +785557 75455 rinur@yandex.ru

Игорь Карякин Центр полевых иссиеАований 603109, Россия г. Нижний Новгород, ул. Нижегородская, 3-29 тел.: +7831433 3847 ikar_research@mail.ru
Резюме

В работе Центра кольцевания хишных птиц Российской сети изучения и охраны пернатых хишников в 2015 г. участвоваяи 35 орнитологов-исследователей и любителей птиц, которые в общей сложности окольцевали 752 особи 22 видов соколообразных и сов. Из меченых птиц мидируют степной орёл (Aquila nipalensis) - 281 особь, орёл-могильник (Aquila heliaca) - 91 особь, скопа (Pandion haliaetus) - 72 особи, орлан-белохвост (Haliaeetus albicilla) - 73 особи, и курганник (Buteo rufinus) - 65 особей. За период с 1 июня 2015 г. Ао 30 мая 2016 г. получена информация о регистрации 46 птиц с кольцами, из которых 38 удалось идентисицировать. Среди ицентисрицированных птиц с кольцами мидируют скопа и орлан-белохвост (по 10 особей), орёл-могильник (6 особей).

Киючевые слова: пернатые хищники, хищные птицы, цветное мечение, кольцевание.

Поступима в редакцию: 11.12.2016 г. Принята к публикации: 27.12.2016 г.

\section{Abstract}

In work of the Raptor Ringing Center of the Russian Raptor Research and Conservation Network in 2015 participated 35 ornithologists-researchers and birdwatchers who have ringed in total 752 individuals of 22 species of birds of prey and owls. From colour ringed birds the leaders are Steppe Eagle (Aquila nipalensis) - 281 ind., Eastern Imperial Eagle (Aquila heliaca) - 91 ind., Osprey (Pandion haliaetus) - 72 ind., White-Tailed Eagle (Haliaeetus albicilla) - 73 ind., and Long-Legged Buzzard (Buteo rufinus) - 65 ind. For period from 1 June 2015 - 30 May 2016 the information was received about the registration of 46 birds with rings from which 38 birds were identified. Among recoveries the leaders are Osprey (10 ind.), White-Tailed Eagle (10 ind.) and Eastern Imperial Eagle (6 ind.).

Keywords: birds of prey, raptors, colour ringing, tagging.

Received: 11/12/2016. Accepted: 27/12/2016.

DOI: $10.19074 / 1814-8654-2016-33-24-45$ 
Мирослав Бабушкин $\triangle$ Арвинский заповеАник 162606, Россия, Вологодская область, г. Череповец, пр. Победы, 6-3 тел.: +78202570258 babushkin02@mail.ru

Сергей Важов Аитайская государственная акацемия образования им. В.М. Шукшина, 659333, Россия, Аитайский край, г. Бийск,

ул. Короленко, 53 тел.: +79635348107 aquila-altai@mail.ru

Алексей Левашкин Архитектурно-этнографический музей-заповеАник "Шёлковский хутор"

603081, Россия, г. Нижний Новгород, ул. Горбатовская, 41 тел.: +7950 3652751 aple_avesbp@mail.ru

Вамерий Пименов Природный парк "Волго-Ахтубинская пойма" 404143, Россия, Волгограцская обл., пос. Средняя Ахтуба, Набережная, 2-а pimenova@inbox.ru

Васииий Пчелинцев Санкт-Петербургский государственный университет

199034, Россия,

Санкт-Петербург,

Университетская наб., 9 vapis@mail.ru

\section{Contact:}

Rinur Bekmansurov, Elabuga Institute, Kazan Federal University; National Park

"Nizhnyaya Kama" Kazaknskaya str., 89 Elabuga Republic of Tatarstan 423600, Russia tel.: +785557 75455 rinur@yandex.ru

Igor Karyakin Center of Field Studies Nizhegorodskaya str., 3-29 Nizhniy Novgorod Russia, 603109 tel.: +7831433 3847 ikar_research@mail.ru

\section{Введение}

Программа Центра кольцевания хишных птиц Российской сети изучения и охраны пернатых хишников ${ }^{23}$ продолжила своё развитие в 2015 г. Этот четвёртый год работы программы вновь имел положительные результаты, отражённые, как в масштабах проведённых исследований, так и в результатах получения информации о регистрации окольцованных птиц, вкАючая наблюдения живых птиц в природе и возвраты колец в результате гибели птиц.

В Аанном обзоре обобщены результаты программы кольцевания за 2015 г., а инсормация о возвратах приводится С последней Ааты в предыдушем отчёте 1 июня 2015 г. (Карякин и Ар., 2015) $\Delta$ о начала следуюшего этапа наиболее массового кольцевания с условной Аатой 30 мая 2016 г. В Аанный обзор также вкиючена инсормация о возвратах колец, не попавших в предылуший отчёт, по причинам позднего получения инсормации о них.

\section{Результаты программы}

Информация о кольцах, применяемых в программе кольцевания хишных птиц, и цветовых схемах, разработанных мия нескольких регионов России и Казахстана, подробно приведена в предылушем отчёте (Карякин и мр., 2015), а также на интернет-сайте Российской сети изучения и охраны пернатых хишников в разделе «Кольцевание " ${ }^{24}$. Поэтому в Аанном сообщении приведены главным образом результаты кольцевания и инсормация о регистрациях окольцованных птиц в природе (возвратах колец).

\section{Результаты кольцевания}

В 2015 г. в программе цветного мечения хишных птиц участвовами 35 орнитологов-исследователей и мюбителей птиц, которые в обшей сложности окольцевами 752 особи 22 видов соколообразных и сов в 17 субъектах Российской Федерации (Астраханская, Волгограцская, Вологодская, Аенинграхская, Нижегородская, Новосибирская, Оренбургская, Псковская, Сверциовская, Ульяновская, Ярославская области, республики Алтай, Башкирия, Крым, Татарстан, Чувашия, Алтайский край) и 2-х областях Казахстана (Актюбинская, Запанно-Казахстанская области). Из меченых птиц мидируют степной орёл (Aquila nipalensis) - 281 особь, орёл-могильник (Aquila heliaca) - 91 особь, скопа

\section{Introduction}

The program of color marking of raptors in the Russian Raptor Research and Conservation Network (further RRRCN) continues to developing in 2015. In the given review the results of the program and its updating for 2015 , and the information on recoveries is published for the period from June, $1^{\text {st }}, 2015$ till June, $1^{\text {st }}, 2016$ inclusive. Information on recoveries in the past period is available in a previous publication (Karyakin et al., 2015).

\section{Results of the program \\ Results of ringing}

In 2015 in the program of color ringing of raptors 35 ornithologists-researchers and birdwatchers were participating, who in total have ringed 752 individuals of 22 species of birds of prey and owls in 2 regions of Kazakhstan (Actobe and Western Kazakhstan regions) and 17 regions of the Russian Federation (Astrakhan, Volgograd, Vologda, Leningrad, Nizhniy Novgorod, Novosibirsk, Orenburg, Pskov, Sverdlovsk, Ulyanovsk, Yaroslavl regions, republics of Altai, Bashkortostan, Crimean, Tatarstan, Chuvashiya and Altai Kray).

From ringed birds the leaders are Steppe Eagle (Aquila nipalensis) - 281 individuals, Imperial Eagle (Aquila heliaca) - 91 individuals, Osprey (Pandion haliaetus) - 72 individuals, White-Tailed Eagle (Haliaeetus albicilla) - 73 individuals, Long-Legged Buzzard (Buteo rufinus) - 65 individuals (table 1 ).

Ringing was carried out by several groups. The biggest quantity of birds (mainly Steppe Eagles) were ringed in Kazakhstan (Actobe and Western Kazakhstan regions) by the group under the direction of I. Karyakin (participants L. Zinevich and M. Kalashnikov) and in the Republic of Kalmykia by I. Karyakin, A. Matsina and M. Korolkov - 168 and 105 birds, respectively. In the Republic of Tatarstan R. Bekmansurov ringed 120 raptors, mainly Imperial Eagles and WhiteTailed Eagles. In the Altai Kray S. Vazhov, R. Bachtin, N. Zaitsev and E. Fomina ringed 59 raptors, mainly Steppe Eagles and LongLegged Buzzards, and V. Plotnikov and E. Shnayder ringed 9 Peregrine Falcons (Falco peregrinus) and 7 Saker Falcons (Falco cherrug) released into the wild in the territory of the Reserve "Kisluhinskiy" (these falcons were confiscated from poachers). M. Babushkin in Vologda and Yaroslavl regions ringed 90 individuals of Ospreys and White-Tailed Eagles. In the N. Novgorod

\footnotetext{
23 http://rrrcn.ru/ru/ringing

24 http://rrrcn.ru/ringing/obraztsyi-kolets/3
} 
Miroslav Babushkin Darwin State Nature Biosphere Reserve Pobeda ave., 6-3, Cherepovets, Vologda region, Russia, 162606 tel.: +78202 570258 babushkin02@mail.ru

Sergey Vazhov The Shukshin Altai State Academy of Education, Korolenko Str., 53 Biysk, Altai Kray, Russia, 659333 tel.: +79635348107 aquila-altai@mail.ru

Aleksey Levashkin Architectural and Ethnographic MuseumReserve "Schelkovskiy Hutor"

Gorbatovskaya str., 41, Nizhniy Novgorod, Russia, 603081 tel.: +79503652751 aple_avesbp@mail.ru

Valeriy Pimenov Nature Park "VolgoAhtubinskaya poyma" pimenova@inbox.ru

Vasiliy Pchelintsev Saint-Petersburg State University Universitetskaya quay, 9 St.-Petersburg Russia, 199034 vapis@mail.ru
(Pandion haliaetus) - 72 особи, орлан-бемохвост (Haliaeetus albicilla) - 73 особи, и курганник (Buteo rufinus) - 65 особей (табл. 1).

Кольцевание осушествлялось несколькими группами. Наибольшее количество птиц, главным образом степных орлов, было окольцовано в ходе выполнения программы по изучению степного орла, поццержанной проектом ПРООН/ГЭФ/ Минприроды России "Совершенствование системы и механизмов управления ООПТ в степном биоме России" в Казахстане в Актюбинской и Запанно-Казахстанской областях (134 и 34 особи соответственно) группой под руководством И. Карякина (участники А. Зиневич и М. Камашников), а также в Республике Каммыкии (105 особей) И. Карякиным, А. Мацыной и М. Корольковым. В Республике Татарстан Р. Бекмансуровым окольцованы 120 птиц, в основном орлы-могильники и орланы-белохвосты. В Алтайском крае С. Важов, Р. Бахтин, Н. Зайцев и Е. Фомина окольцевами 59 хишных птиц. Также В. Плотниковым и Е. Шнайдер были помечены изъятые у браконьеров 9 сапсанов (Falco peregrinus) и 7 бамобанов (Falco cherrug) перед их выпуском в прирому на территории Кислухинского заказника. В Ярославской и Вологодской области М. Бабушкиным окольцовано 90 хишников (скопа и орлан-белохвост). В Нижегородской области кольцеватели А. Аевашкин и Г. Колотин пометили 50 птиц, преимушественно луговых муней (Circus pygargus) и сов. Большая международная группа исследователей под руководством В. Пчеминцева занимамись кольцеванием скопы и орлана-белохвоста в Псковской и Аенингралской областях, гле было помечено 43 птицы. На Ураче мечение сапсанов продолжаи А. Хиопотова, М. Шершнев (Сверциовская область) и В. Алексеев (Башкирия) ими в обшей сложности было окольцовано 18 соколов. В Новосибирской области в программе по мечению коршунов (Milvus migrans) участвоваии $\Delta$. Штоль, Э. Николенко, А. Милежик, Е. Шнайдер. В Волгограцской области степных орлов и курганников метили В. Пименов и М. Байбаков. В Республике Аитай продолжено кольцевание хишных птиц И. Карякиным, Э. Николенко и Е. Шнайдер. В Чувашии кольцеваии орлановбелохвостов Р. Бекмансуров и Г. Исаков. Необходимо также отметить мечение хищных птиц, прошедших лечение и реабилитацию после получения различных травм и подготовленных к выпуску в естественные условия обитания. Так представителем region A. Levashkin and $\mathrm{G}$. Kolotin ringed 50 raptors, mainly Montagu's Harriers (Circus pygargus) and owls. A large international team of researchers under the direction of V. Pchelintsev ringed 43 Ospreys and White-Tailed Eagles in the Pskov and Leningrad regions. Also ringers worked in the Sverdlovsk region - A. Khlopotova and M. Shershnev, in the Republic of Bashkortostan - V. Alekseev, in the Novosibirsk region - D. Shtol, E. Nikolenko, A. Milezhik and E. Shnayder, in the Volgograd region - V. Pimenov and M. Bajbakov, and other regions.

\section{Recoveries}

From 1 June 2015 to 30 May 2016 the information on registration of 46 birds with rings is received from which it was possible to identify 38: 36 - recoveries of birds in Russia and Kazakhstan was ringed on RRRCN schemes (table 2) and 3 recoveries was ringed on other schemes, 5 recoveries - a foreign birds in Russia (table 3 ) and 2 recoveries - a foreign birds in other countries.

\section{Discussion}

Ringing of birds of prey with colored rings has shown again its advantage in the identification of birds in nature. Because of the application of this method during the reporting period 27 birds with colored rings were photographed in nature by different observers, 4 birds of them were photographed using specially installed camera traps. Twenty one birds were identified among them (Osprey - 8, White-Tailed Eagle - 11, Imperial Eagle - 1, Greater Spotted Eagle - 2), and ringing regions were identified for 5 White-Tailed Eagles by colors of rings. Registrations of birds living in nature are the most pleasant news. The geography of birdwatchers work can be observed thereon. Information about photo observations came from such foreign countries as Bulgaria, Cyprus, Mozambique, Cameroon, Republic of South Africa, Israel, Oman. Information from the regions of Russia came mainly from regions where ornithologists are working hard and there are teams of bird-fanciers and animalists photographers from Yaroslavl, Ulyanovsk and Pskov regions, the Republic of Tatarstan.

During the reporting period, the record was made on the distance of the migration of birds ringed within the RRRCN program. Champions are 2 Ospreys ringed by Miroslav Babushkin in Yaroslavl (Darwin Reserve) and Vologda regions. In both cases, these were observations of 
Табл. 1. Сводка по мечению птиц в 2015 г.

Table 1. Short report about the birds ringing in 2015.

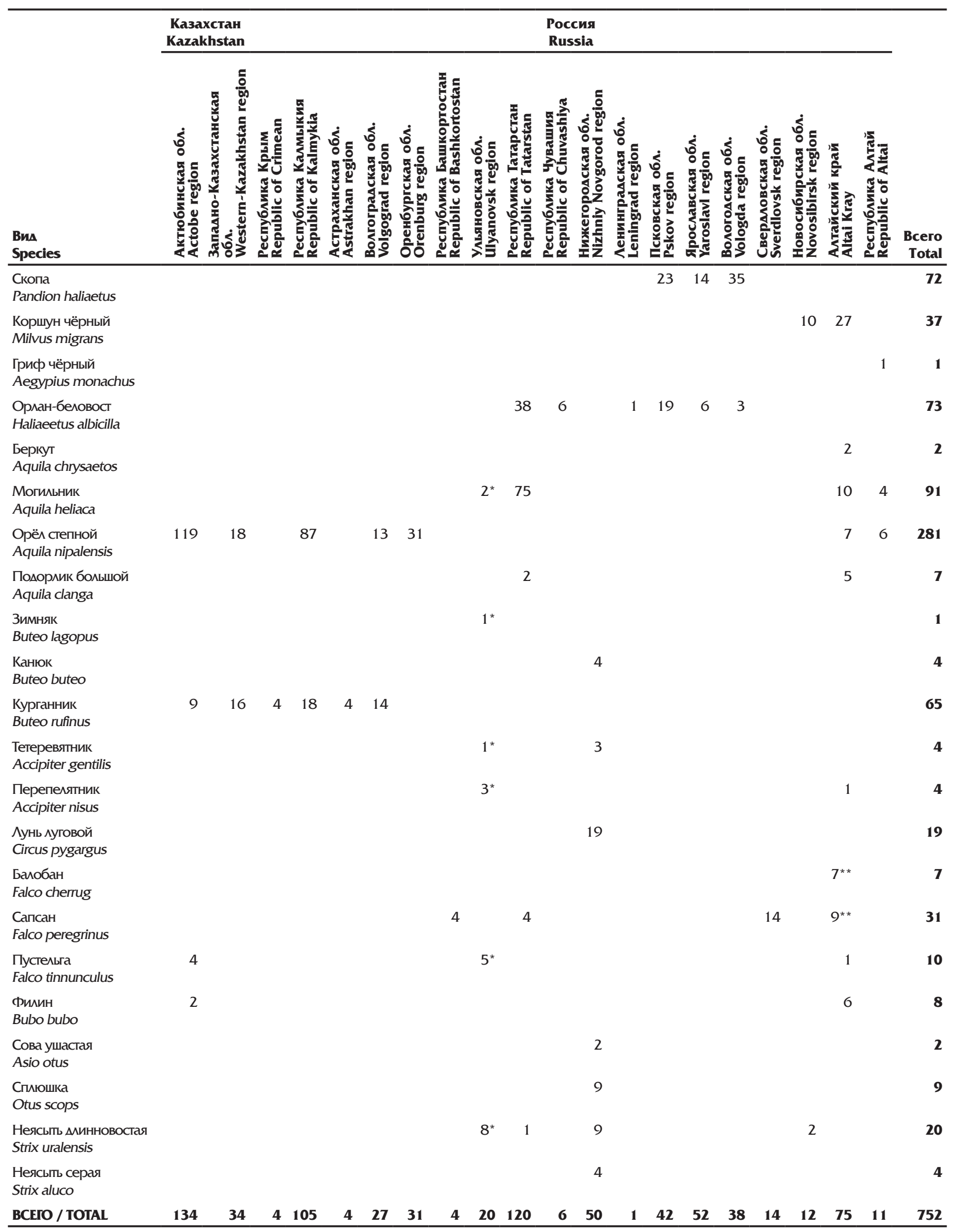

Примечание / Note:

* - птицы выпушенные в природу после реабилитации / birds released into the wild after rehabilitation

** - выпушенные в природу соколы, изъятые у браконьеров / falcons confiscated from poachers and released into the wild 
Регионаиьной зоозашитной обшественной организацией "Симбирский центр спасения Аиких животных" Г. Пилюгиной выпушены на волю 20 птиц, которые предварительно были помечены специальными цветными кольцами.

\section{Возвраты}

За период с 1 июня 2015 г. по 30 мая 2016 г. получена инсормация о регистрации 46 птиц с кольцами, из которых 38 удалось идентифицировать. Из этих Аанных: 36 наблюдений - возвраты птиц, помеченных в России и Казахстане по схемам программы RRRCN (табл. 2) и 3 наблюдения - возвраты российских птиц, помеченных по Аругим схемам и программам, 5 - возвраты зарубежных птиц в России (табл. 3), 2 наблюдения - возвраты зарубежных птиц из Аругих стран.

Возвраты колец и регистрации птиц, окомьцованных в России и Казахстане

\section{1. Скопа (Pandion haliaetus)}

1.1. Скопа (птенец), окольцованная 13 июля 2015 г. Василием Пчелинцевым, Гуннаром Сейном (Gunnar Sein) и Михкелем Тийло (Mihkel Tiido) в гнезде, расположенном на побережье Псковско-Чудского озера в Псковской области на границе с Эстонией (номера колец I-79, цветовая схема мия северо-запада России) ${ }^{25}$, была сфотографирована болгарскими коммега- birds living in nature on distances from the place of ringing $8,949.5 \mathrm{~km}$ (in Mozambique) and $10,553.0 \mathrm{~km}$ (in Republic of South Africa).

We have received the first registrations of Imperial Eagles wintering in Oman, moreover 2 birds are from one breeding group in Tatarstan. Registrations of Imperial Eagles, the youngest in broods of 3 nestlings, show again that with good feeding situation pairs of eagles are able to successfully bring up these large broods, contrary to the most popular stereotypes about the survival of only older nestlings of eagles.

We have received additional information about repeated observations of birds in wintering grounds. Thus three WhiteTailed Eagles, born on the territory of Tatarstan, were photographed on a winter gathering in the Ulyanovsk region. Two of them were registered for the second year in a row, and one with a break of two years.

Information has been accumulated about monitoring of ringed birds near the places of their birth, which subsequently allow conducting phylopatry analysis. For example, during the breeding season of 2015 in Tatarstan only one ringed bird was found among 45 young birds, which legs were examined remotely. It should also be noted that in similar volumes of White-Tailed Eagles ringing in the Darwin Reserve, the

Табл. 2. Возвраты птиц во второй половине 2015 - первой половине 2016 гг. (только возвраты птиц, окольцованных в России и Казахстане по программе RRRCN).

Table 2. The recoveries of birds were received in second half of 2015 - first half of 2016. (Only the recoveries of birds ringed in the RRRCN programme in Russia and Kazakhstan).

\begin{tabular}{|c|c|c|c|c|c|c|c|c|c|c|c|c|c|c|c|c|}
\hline $\begin{array}{l}\text { Вих } \\
\text { Species }\end{array}$ & 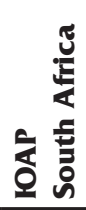 & 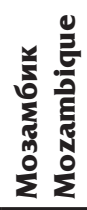 & 좇 & 졸 & छ్ & 촐 흘 & 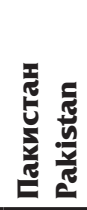 & 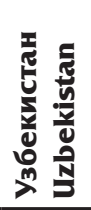 & 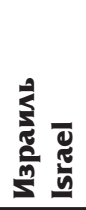 & $\stackrel{\frac{5}{5}}{\frac{5}{5}} \frac{x}{\sqrt{5}}$ & 틀 & 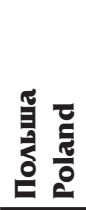 & 突 & 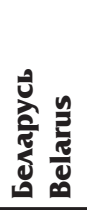 & 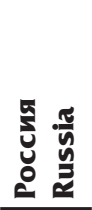 & $\begin{array}{r}\text { Bcero } \\
\text { Total }\end{array}$ \\
\hline $\begin{array}{l}\text { Скопа } \\
\text { Pandion haliaetus }\end{array}$ & 1 & 1 & 1 & & & & & & 1 & & 1 & & 1 & & & 6 \\
\hline $\begin{array}{l}\text { Орлан-белохвост } \\
\text { Haliaeetus albicilla }\end{array}$ & & & & & & & & & & & & 1 & & 1 & 14 & 16 \\
\hline $\begin{array}{l}\text { Oрёл-могильник } \\
\text { Aquila heliaca }\end{array}$ & & & & & 2 & & & 1 & & & & & & & 3 & 6 \\
\hline $\begin{array}{l}\text { Oрёл степной } \\
\text { Aquila nipalensis }\end{array}$ & & & & & & 1 & 1 & & & & & & & & 2 & 4 \\
\hline $\begin{array}{l}\text { Курганник } \\
\text { Buteo rufinus }\end{array}$ & & & & & & & & & & 1 & & & & & & $\mathbf{1}$ \\
\hline $\begin{array}{l}\text { Сапсан } \\
\text { Falco peregrinus }\end{array}$ & & & & & & & & & & & & & & & 3 & 3 \\
\hline $\begin{array}{l}\text { BCEIO } \\
\text { TOTAL }\end{array}$ & $\mathbf{1}$ & 1 & 1 & & 2 & 1 & 1 & $\mathbf{1}$ & 1 & 1 & 1 & 1 & $\mathbf{1}$ & $\mathbf{1}$ & 22 & 36 \\
\hline
\end{tabular}

25 http://217.112.43.140/report/3916 
Табл. 3. Возвраты зарубежных птиц в России во второй половине 2015 - первой половине 2016 гг.

Table 3. The birds recoveries from the foreign countries in Russia in second half of 2015 - first half of 2016

\begin{tabular}{|c|c|c|c|c|c|}
\hline Вим / Species & $\begin{array}{l}\text { Швеция } \\
\text { Sweden }\end{array}$ & $\begin{array}{r}\text { Финляндия } \\
\text { Finland } \\
\end{array}$ & $\begin{array}{r}\text { Латвия } \\
\text { Latvia } \\
\end{array}$ & $\begin{array}{l}\text { Венгрия } \\
\text { Hungary }\end{array}$ & $\begin{array}{r}\text { Bcero } \\
\text { Total } \\
\end{array}$ \\
\hline $\begin{array}{l}\text { Скопа } \\
\text { Pandion haliaetus }\end{array}$ & & 2 & 1 & 1 & 4 \\
\hline $\begin{array}{l}\text { Орлан-белохвост } \\
\text { Haliaeetus albicilla }\end{array}$ & 1 & & & & 1 \\
\hline BCEIO / TOTAL & 1 & $\mathbf{1}$ & $\mathbf{1}$ & $\mathbf{2}$ & 5 \\
\hline
\end{tabular}

ми на Марашском водохранилише в Болгарии. Об этом было получено осрициальное сообшение из Болгарского центра кольцевания ${ }^{26}$. Птица наблюдамась с 20 по 26 сентября 2015 г. Аистанция - 1676 км, азимут - 182 градусов, продолжительность -75 Аней ${ }^{27}$.

1.2. Скопа (птенец), окольцованная 11 июля 2013 г. Мирославом Бабушкиным в гнезде на территории Аарвинского заповедника в Ярославской области (номера колец F-18, цветовая схема мля Верхней Волги) ${ }^{28}, 5$ октября 2015 г. встречена на Кипре на водохранилище Ачна (Achna Dam), о чём сообшил Аиан Крабтри (Alan Crabtree) из Кипрского центра кольцевания ${ }^{29}$. Аистанция - 2636 км, азимут - 189 грапусов, продолжительность - 817 Аней (2 года и 2 месяца) ${ }^{30}$.

1.3. Скопа (птенец), окольцованная 13 июля 2013 г. Мирославом Бабушкиным в гнезде на территории Аарвинского заповедника в Ярославской области (номера колец F-13, цветовая схема мля Верхней Волги) ${ }^{31}, 8$ ноября 2015 г. была отмечена в провинции Инхамбане в Мозамбике на побережье Мозамбикского пролива. Эту охотяшуюся скопу ссотографиироваяи Анspe Янковский (Andre Jankowski) и Фрила Милисия (Frida Milice), о чём сообшил Айгарс Камьванс (Aigars Kalvans) ${ }^{32}$. Аистанция - 8949,5 км, азимут - 182,5 грапуса, продолжительность - 849 Аней (2 года и 4 месяца) $)^{33}$.

1.4. Скопа (птенец), окольцованная 9 июля 2013 г. Мирославом Бабушкиным в гнезде на Шекснинском водохранилише в Вологодской области (номера колец F-09, percentage of birds' recoveries to the natal area is at least 3 times higher over the same period. In the Upper Volga population, young birds leaving is perhaps lower for a variety of anthropogenic reasons, or lower is the level of post-breeding dissemination of birds, not returning to the breeding grounds in the following years and settling in other territories. It is possible that a high level of natal recoveries in the Darwin Reserve is associated with the use of camera traps, as only the visual observation a priori gives lower results in terms of registration of birds with rings.

During the reporting period, additional information was obtained on several important issues: (Karyakin et al., 2015)

5) causes of deaths or injuries of birds, i.e. their vulnerability to the migration routes;

6) directions and distances of migrations, wintering grounds and stopping points;

7) life span at least till the date of meeting, as well as vulnerable age group;

8) dependence of the causes of death or injury on the direction and distance of migration.

Among the 38 identified birds, 19 fell into the hands of a man in different circumstances. Electrocution in power lines dangerous to birds is recorded for Osprey (age 3 years) in the Pskov region, fledgling of Imperial Eagle in Tatarstan and a bird at the age of 1.5 years in Uzbekistan (bird successfully survived two winters and died in the initial stage of the second spring migration). Another Imperial Eagle died in a collision with wires of power lines in the Altai region, returning to the natal area after the successful wintering.

A new topic for discussion has also appeared - it is a problem of catching birds on migration routes and wintering areas for commercial purposes. Thus Osprey in Cameroon (a bird died), Steppe Eagle in Pakistan, Peregrine Falcons in Iraq and Libya were caught. In the latter case, according to the respondent bird was sold to a dealer of falcons from Egypt for 9 thousand US dollars.

Not the first information about the death of Imperial Eagles from Tatarstan on migrations and wintering grounds shows that

\footnotetext{
http://217.112.43.140/report/3917

http://rrrcn.ru/forum/viewtopic.php?f=4\& $t=259 \&$ start $=40 \# p 2657$

http://217.112.43.140/report/2465

http://217.112.43.140/report/4056

http://rrrcn.ru/forum/viewtopic. $p h p ? f=4 \& t=259 \&$ start $=60 \# p 2723$

http://217.112.43.140/report/2460

http://217.112.43.140/report/4261

http://rrrcn.ru/forum/viewtopic.php?f=4\& $t=2598$ start $=90 \# p 2848$
} 


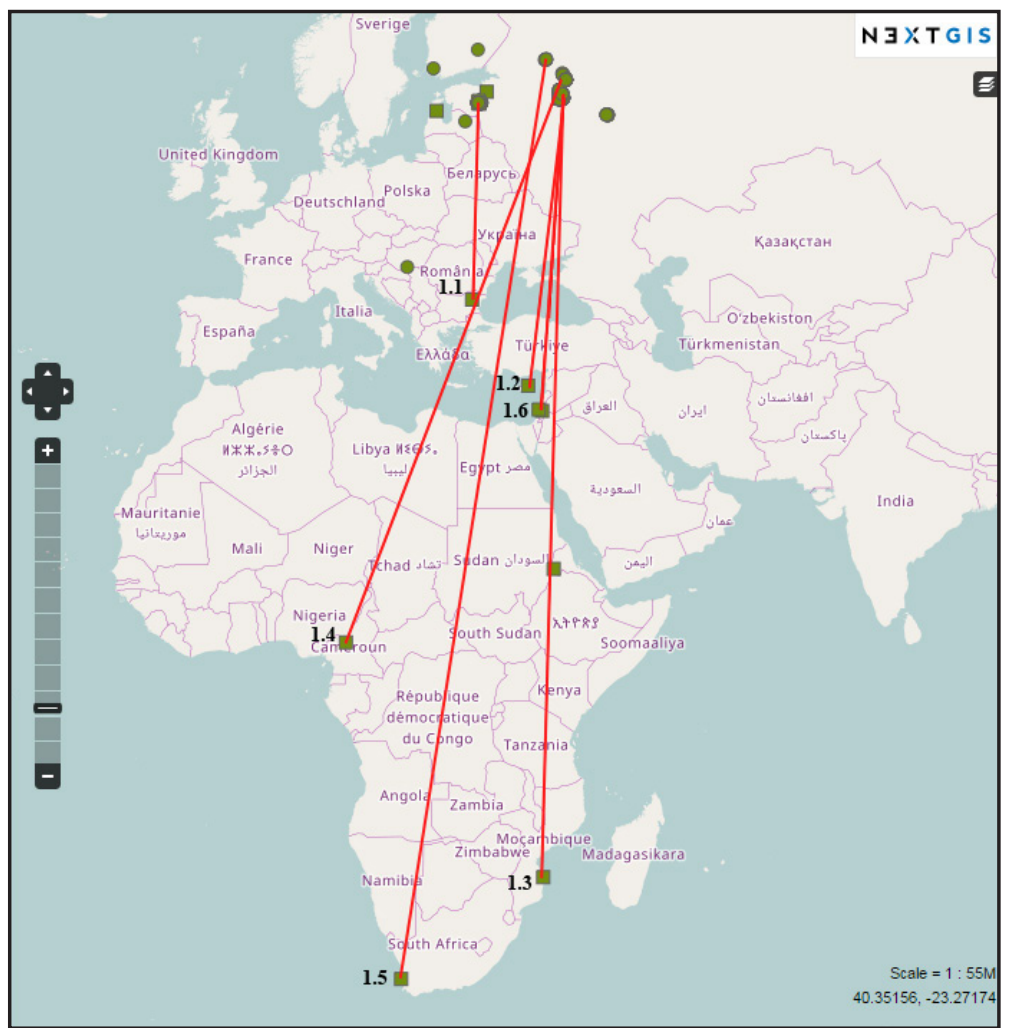

цветовая схема мяя Верхней Волги) ${ }^{\mathbf{3 4}}, 13$ Аекабря 2015 г. отловлена в Камеруне ${ }^{35}$. Респонденты: ОАилон Геанджим (Odilon Gheahnjim), Роджер Кивен (Roger Kiven Wikinyuy). Из Камеруна поступами дополнительные сообшения о содержании этой птицы в неволе и коммерческие предложения о её выкупе. Сотрудники Российского посольства в Камеруне сделаии попытку спасти птицу, но это не удалось, и птица погибла. Аистанция - 6390 км, азимут - 212 градусов, продолжительность 888 Аней $(2,5 \text { года })^{36}$.

1.5. Скопа (птенец), окольцованная 11 июля 2015 г. Мирославом Бабушкиным в гнезде близ побережья Онежского озера в Вологодской области (номера колец Е-41, цветовая схема мия Верхней Волги) ${ }^{37}, 13$ февраля 2016 г. ссотограсрирована Мишелем Бэкхэмом (Michael Buckham) близ побережья Атлантического океана в провинции Западный мыс ЮАР (West Coast National Park) в 90 км к северо-западу от Кейптауна ${ }^{38}$. Аистанция - 10553 км, азимут - 195 грацусов, продолжительность жизни - 218 Аней (семь с небольшим мес.) ${ }^{39}$. На сегодняшний день это самое Аальнее зимнее наблюдение российских скоп.
Рис. 1. Схемы возвратов от скоп (Pandion haliaetus), помеченных в рамках программы цветного мечения хишных птиц Российской сети изучения и охраны пернатых хишников за 2015-2016 гг. Нумерация возвратов соответствует нумерации в тексте.

Fig. 1. Schemes of recoveries from Osprey (Pandion haliaetus), ringed within the limits of the Raptor Color Ringing Program of the Russian Raptor Research and Conservation Network during the period 2015-2016. Numbering of recoveries in figure correspond to those in text.

a significant part of young eagles will not return to places of their birth. Apart from the electrocution on power lines, being essential, poisoning and shooting act as a direct factor limiting the population (table 4). However, not only young birds die on power lines, which seems to be easier to adapt than to poisoning, but also sub-adult, which have successfully gone through several seasons and made long migrations.

Birds of prey often die from collisions with vehicles. This is probably due to rodent hunting often making their colonies on road borders. During this reporting period the message was received about the death of ringed Steppe Eagle fledgling killed on the motorway near its nest in the Orenburg region.

Special mention must be made of cases of injured birds and their deaths as a result of natural interspecies relationships. Thus, in the Orenburg region the case was registered about the injury of already ringed Steppe Eagle nestling by quadruped predator on the nest, located on the ground. We identified the case of death of ringed Peregrine Falcon nestlings in the Urals in the South Ural reserve in the attack of Eagle Owl on the nest. Long-Legged Buzzard suffered an injury and later was killed in an attack of Eagle in Syria.

Analysis of various negative factors influencing on the birds of prey is not the purpose of this review, however, these data are important for those who are engaged in study and conservation of birds of prey in the regions. These data provide an understanding of the level of birds' survival and have a critical approach to the assessment of the adverse factors in general, affecting the populations, and not to hope on the habitat dislocation in the breeding grounds. 


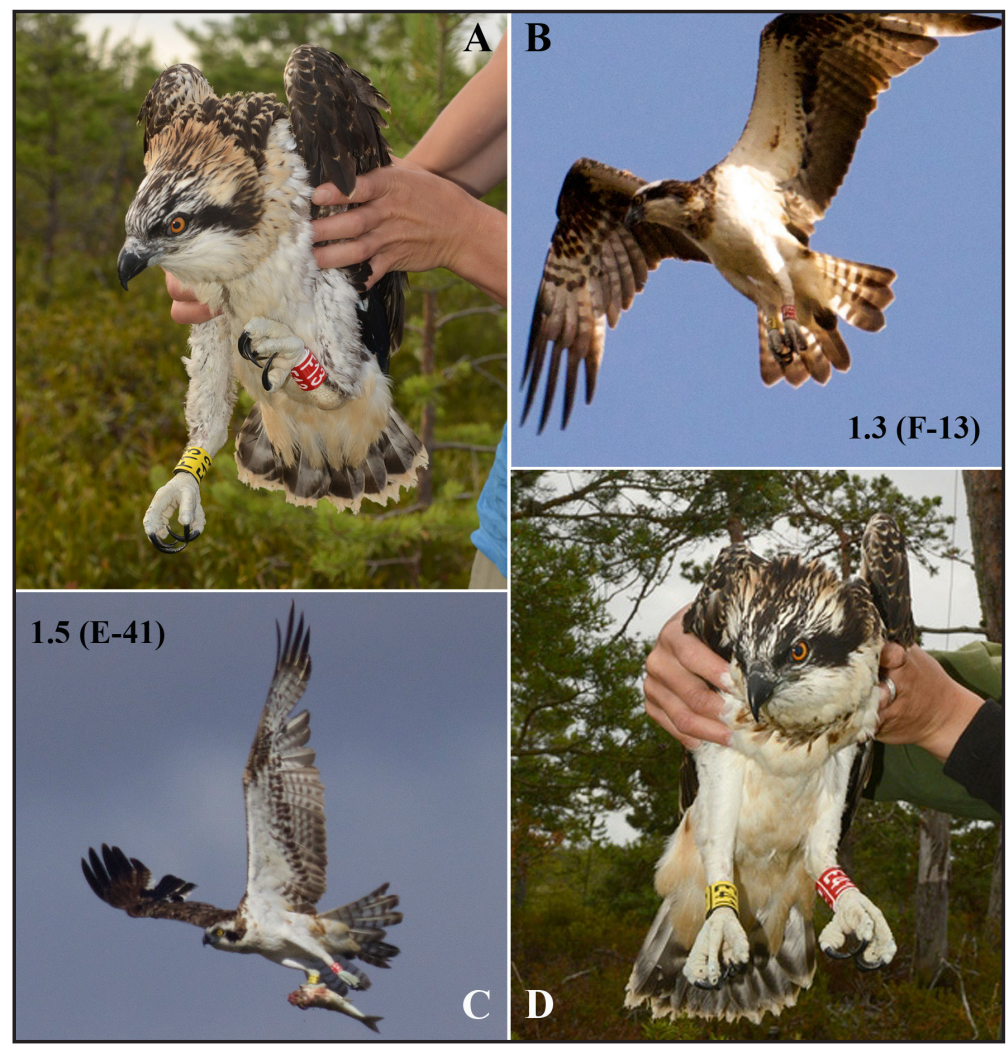

1.6. Скопа (птенец), окольцованная 20 июля 2014 г. Мирославом Бабушкиным в гнезде на территории Аарвинского заповедника (номера колец F-91, цветовая схема мия Верхней Волги) ${ }^{40}, 15$ апреля 2016 г. сротограсирована на зимовке в Израиле в районе населённого пункта Хазориа (Hazorea). Птицу ссотограсрироваи Ори Аммог (Ori Almog ${ }^{41}$. Аистанция - 2895 км, азимут - 186 грацусов, продолжительность жизни - 636 Аней (нескольким более полутора лет) ${ }^{42}$.

\section{2. Орлан-белохвост} (Haliaeetus albicilla)

2.1. Молодой орлан-белохвост 9 ян-

Скопа, окольцованная 20 июля 2014 г. в Аарвинском заповеднике (A), 15 апреля 2016 г. встречена на зимовке в Израиле (B).

Фото М. Бабушкина и О. Аимога.

Osprey was ringed in the Darwin State Nature Reserve in July 20 ,

2014 (A) was observed on wintering in Israel in April 15, 2016 (B). Photos by M. Babushkin and Ori Almog.
Наблюдения российских скоп (Pandion haliaetus) с цветными кольцами в Асрике: птица, окольцованная 13 июля 2013 г. в Аарвинском заповеднике (А), 8 ноября 2015 г. встречена в Мозамбике на побережье Мозамбикского пролива (В); птица, окольцованная 11 июля 2015 г. на Онежском озере в Вологодской области (С), 13 февраля 2016 г. встречена близ побережья Атлантического океана в провинции Запацный мыс ЮАР (D).

Фото М. Бабушкина, Ф. Мимисии и М. Бэкхэма.

Observations of the Russian Ospreys (Pandion haliaetus) with coloured rings in Africa: bird was ringed in the Darwin State Nature Reserve in July 13, 2013 (A), and was observed in Mozambique on the coast in 8 November 2015 (B); bird was ringed near the Onezhskoe Lake in the Vologda region in July 11,2015 (C), and was observed on the coast of the Atlantic Ocean in the West Coast National Park in South Africa in 13 February 2016 (D).

Photos by M. Babushkin, M. Buckham, F. Milice.

фотоловушкой на привале в окрестностях А. Сосновый Бор Россонского района Витебской области, Беларусь (респондент: Аенис Китель) ${ }^{43}$. На птице имелись цветные кольца схемы кольцевания для Северо-Запала России. Василий Пчелинцев, группой которого метились орланы такими кольцами в 2014 г., сообшил, что наиболее вероятной точкой кольцевания этого орлана является РемАовский заказник на берегу ПсковскоЧудского водоёма ${ }^{44}$. Вероятная Аистанция - около 257 км, азимут - около 169 градусов, продолжительность - около полугода.

2.2. Молодой орлан-белохвост (примерно 2-летнего возраста) с цветными кольцами на лапах по схеме кольцевания мля Средней Волги ссотограсрирован Ринуром Бекмансуровым 26 мая 2015 г. в Республике Татарстан на Куйбышевском водохранилише на территории Государственного природного заказника «Спас-

40 http://217.112.43.140/report/2978

41 http://217.112.43.140/report/4204

42 http://rrrcn.ru/forum/viewtopic.php?f=4\& t=294\& start=10\#p2974

43 http://217.112.43.140/report/4223

44 http://rrrcn.ru/forum/viewtopic. $p h p ? f=4 \& t=2598$ start $=90 \# p 2843$ 


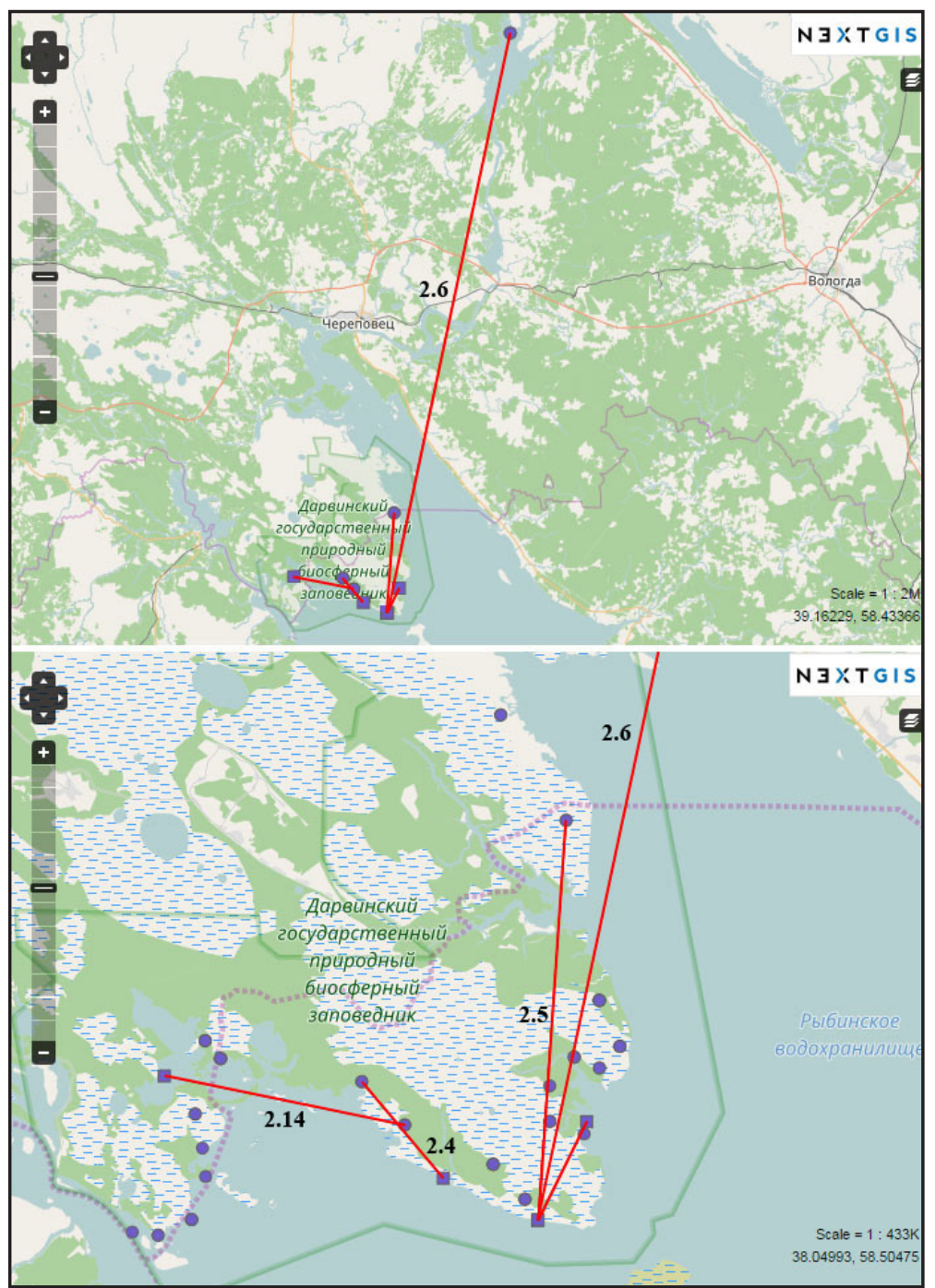

Pис. 2. Натаиьные возвраты орланов-белохвостов (Haliaeetus albicilla), помеченных в Аарвинском заповеднике. Нумерация возвратов соответствует нумерации в тексте.

Fig. 2. Natal recoveries of the White-Tailed Eagles (Haliaeetus albicilla) in the Darwin State Nature Reserve. Numbering of recoveries in figure correspond to those in text.

СКий" ${ }^{45}$. Из-за Аальности наблюдения прочитать коды на кольцах не удалось. Тем не менее, это первое в Среднем Поволжье наблюдение орлана с цветными кольцами в натальной области.

2.3. Орлан-белохвост с узким алюминиевым кольцом Российского центра кольцевания на правой лапе 3 июня 2015 г. был ссотограсирован Ринуром Бекмансуровым во время мониторинга гнездования орланов-белохвостов на гнездовом участке в Сараловском участке ВолжскоКамского заповедника ${ }^{46}$. Вероятный возраст птицы 4-5 лет. Идентисрицировать кольцо не удалось. Но такими кольцами, нацетыми на правую лапу, были помече- ны только 3 птицы (один в 2010 г. и Ава - в 2011 г. - всех птиц метил Р. Бекмансуров), что позволило провести анализ возможных вариантов номеров колец. Так был искиючён орлан с номером кольца АВ-0068, ранее отмеченный под Киевом в 2012 г. (Бекмансуров, 2012; Бекмансуров и Ар., 2012). Этот орлан имел характерный признак в виде пера-альбиноса, хорошо различимого на нижней стороне крыла. Но этого признака не было у орлана, сфотограсрированного 3 июня 2015 г. Остались только 2 варианта. Это орлан, окольцованный в 2010 г. (кольцо AB-0061) на расстоянии более 200 км от Аанного места наблюдения, и ешё один с номером кольца АВ-0067, помеченный в 2011 г. на гнезде рялом с местом наблюдения. Возможно, 3 июня 2015 г. была ссотограсрирована именно эта птица с номером кольца АВ-0067.

2.4. Орлан-белохвост (птенец), окольцованный 7 июня 2014 г. Мирославом Бабушкиным на гнезде в Аарвинском заповеднике (кольца цветовой схемы мия Верхней Волги с номерами АВ-073, A-073) ${ }^{47}, 29$ июня 2015 г. был сфотографирован фотоловушкой, установленной на специально сооруженной присаце на территории того же Аарвинского заповедника (на оконечности Молого-Шекснинского полуострова) ${ }^{48}$. Аистанция - 7,6 км, азимут - 140 градусов, продолжительность - 388 Аней (1 гоА).

2.5. Орлан-белохвост (птенец), окольцованный 17 июня 2013 г. Мирославом Бабушкиным на гнезде в Аарвинском заповеднике (кольца цветовой схемы мля Верхней Волги с номерами АВ-051, A-051) 49 , 6 июля 2015 г. был сротографирован фотоловушкой, установленной на специально сооруженной присаце на территории того же $\triangle$ арвинского заповедника (на оконечности Молого-Шекснинского полуострова) ${ }^{50}$. Аистанция - 24 км, азимут - 184 градуса, продолжительность - 750 Аней (2 года). Интересен фракт, что второй птенец с этого же гнезда с номерами колец АВ-052 и A-052 26 мая 2015 г. также был ссротограсрирован на эту же фотоловушку (Карякин и Ар., 2015).

2.6. Орлан-белохвост (птенец), окольцованный 25 июня 2013 г. Мирославом Бабушкиным на гнезде в Вологодской области (кольца цветовой схемы мля Верхней

\footnotetext{
45 http://rrrcn.ru/forum/viewtopic.php?f=4\&t=259\&start=40\#p2663

46 http://rrrcn.ru/forum/viewtopic. $p h p ? f=4 \& t=259 \&$ start=40\#p2666

47 http://217.112.43.140/report/3616
} 


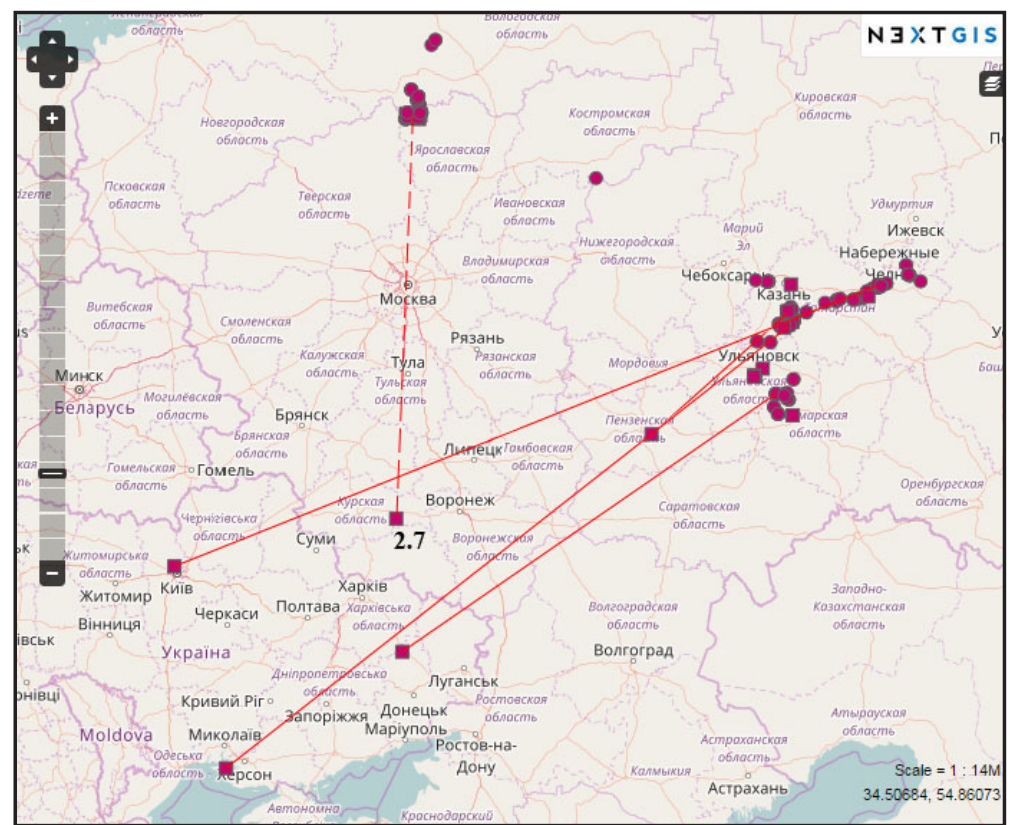

Рис. 3. Ааиьние возвраты волжских орланов-белохвостов. Нумерация возвратов соответствует таковой в тексте.

Fig. 3. Long distance recoveries of the White-Tailed Eagles from Volga river basin. Numbering of recoveries in figure correspond to those in text.

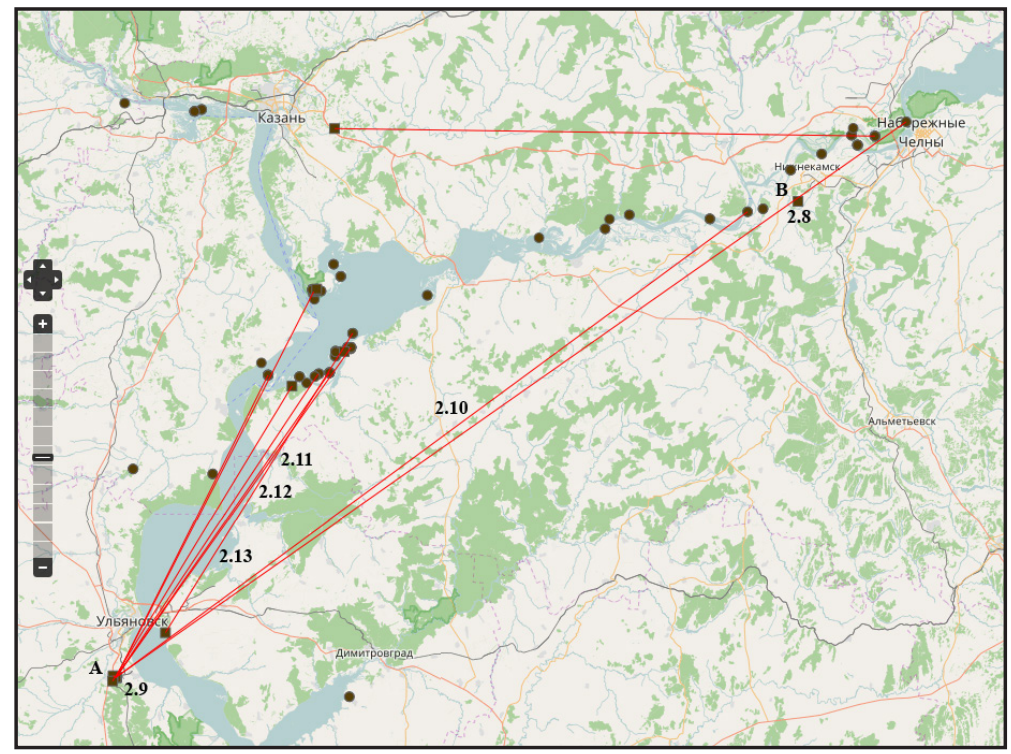

Pис. 4. Наблюдения орланов-белохвостов, помеченных в бассейне Средней Волги: A - зимовка близ Ульяновска, В - зимовка близ Набережных Челнов. Нумерация возвратов соответствует нумерации в тексте.

Fig. 4. Observations of the White-Tailed Eagles ringed in the Middle Volga river basin: A - wintering place near Ulyanovsk, B - wintering place near Naberezhnye Chelny. Numbering of recoveries in figure correspond to those in text.

Волги с номерами АВ-065, А-065) $)^{51}, 12$ июля 2015 г. был сротограсрирован фотоловушкой, установленной на специацьно сооруженной присахе на территории
Аарвинского заповедника в Ярославской области (на оконечности Молого-Шекснинского полуострова) 52 . Аистанция 140,6 км, азимут - 192,2 грахуса, продолжительность - 748 дней (2 года и 1 мес).

2.7. Орлан-белохвост (птенец), помеченный в Аарвинском заповеднике Мирославом Бабушкиным, сфотограсрирован Андреем Власовым 29 октября 2015 г. в Мантуровском районе Курской области на участке Букреевы Бармы ЦентрамьноЧерноземного заповедника ${ }^{53}$. Вероятная Аистанция - около 784 км, азимут - около 183 грацусов, продолжительность - около полугода ${ }^{54}$.

2.8. ОАин из пятнадцати орланов-белохвостов на зимнем скоплении в Нижнекамском районе Республики Татарстан 15 ноября 2015 г. оказался с кольцами (средневолжская схема кольцевания). Птицу ссротограсрироваи Рахик Кутушев ${ }^{55}$. Примерный возраст птицы 2-3 года. Это первая регистрация орлана-белохвоста с кольцами средневолжской схемы кольцевания в зимовочном скоплении на территории Татарстана ${ }^{56}$.

2.9. Молодой орлан-белохвост с кольцами средневолжской схемы кольцевания, 16 мекабря 2015 г. отметился около г. Новоульяновска в Ульяновской области. Птицу наблюдаии Максим Корольков и Ва$\Delta и м$ Вацеков ${ }^{57}$. Из-за большой Аальности $\Delta о$ птицы код на кольце идентисрицировать не уахиось.

2.10. Повторное наблюдение орланабелохвоста на зимнем скоплении в Ульяновской области 8 января 2016 г. ${ }^{58,59}$ В первый раз он был встречен на данном скоплении 2 февраяя 2014 г. $^{\text {60, } 61}$ (Карякин и Ар., 2015). В обоих случаях этого орлана соротограсрировал Михаил Тимофеев. Птица (птенец в возрасте около 70 Аней) была помечена цветными кольцами средневолжской схемы (номера колец: АВ-264, М-264) Ринуром Бекмансуровым 20 июня 2013 г. на гнезде в Мамадышском

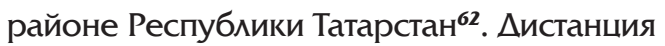
- 257 км, азимут - 235 градусов, продолжительность - 933 Аня (2,5 года).

2.11. Ешё одно повторное наблюдение орлана-белохвоста с такими же цветными кольцами средневолжской схемы (АВ-304, M-304) на зимнем скоплении в УАьянов- \begin{tabular}{ll}
\hline $\mathbf{5 1}$ & http://217.112.43.140/report/2259 \\
$\mathbf{5 2}$ & http://217.112.43.140/report/4307 \\
$\mathbf{5 3}$ & http://217.112.43.140/report/4747 \\
$\mathbf{5 4}$ & http://rrrcn.ru/forum/viewtopic.php?f=4\&t=259\&start=50\#p2691 \\
$\mathbf{5 5}$ & http://217.112.43.140/report/3998 \\
$\mathbf{5 6}$ & http://rrrcn.ru/forum/viewtopic.php?f=4\&t=259\&start=50\#p2703
\end{tabular}

\footnotetext{
57 http://rrrcn.ru/forum/viewtopic.php? $f=4 \& t=2598$ start=90\#p2851

58 http://217.112.43.140/report/4225

59 http://rrrcn.ru/forum/viewtopic.php?f=4\& t=294\#p2845

60 http://217.112.43.140/report/2862

61 http://rrrcn.ru/forum/viewtopic.php?f=4\& t=192\#p1298

62 http://217.112.43.140/report/2118
} 


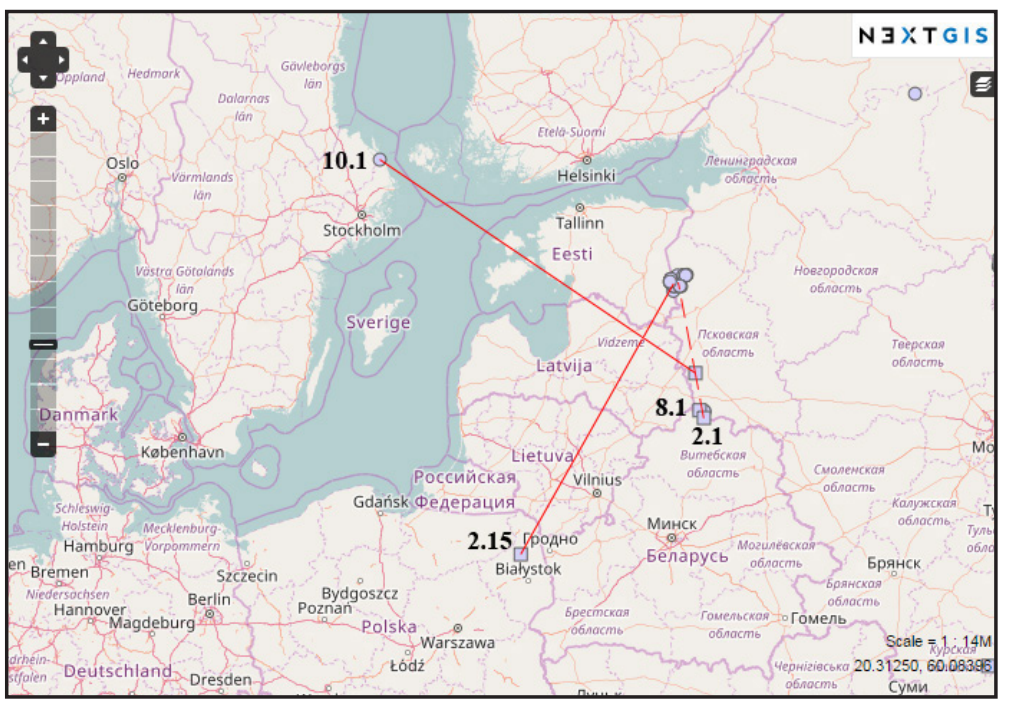

Pис. 5. Все возвраты орланов-белохвостов в Баитийском регионе. Нумерация возвратов соответствует нумерации в тексте.

Fig. 5. All recoveries of the White-Tailed Eagles in the Baltic region. Numbering of recoveries in figure correspond to those in text. ской области слелано 8 января 2016 г. Михаилом Тимосеевым ${ }^{63}$ 59. Первое наблюдение этого орлана на данном скоплении отмечено 3 января 2015 г. ${ }^{64,65}$ Аанный орлан-белохвост (птенец) был окольцован Ринуром Бекмансуровым 30 мая 2014 г. на гнезде в Спасском районе Республике Татарстан $^{66}$. Аистанция - 122 км, азимут 215,5 градусов, продолжительность - 589 Аней (нескольким более 1,5 лет).

2.12. Третий случай повторного наблюдения орлана-белохвоста с цветными кольцами средневолжской схемы (АВ138, М-238) на зимнем скоплении в Ульяновской области 8 января 2016 г. (также ссотограсрирован Михаилом Тимофеевым). ${ }^{67,59}$ Первый раз этот орлан в этом же месте был ссотограсирован Фаритом Зелеевым 27 января 2015 г. ${ }^{68,69}$ (Карякин и мр., 2015). Этот орлан, будучи птенцом, был окольцован Ринуром Бекмансуровым
Орланы-белохвосты окольцованные в $\triangle$ Арвинском заповеАнике и вернувшиеся в заповедник в послеАуюшие годы: птица, 2014 г. (А) встречена 29 марта 2016 г. (B), птица, окольцованная 7 июня 2014 г. (D) снята фотоловушкой 29 июня 2015 г. (С), птица, окольцованная 17 июня 2013 г. (Е) снята фотоловушкой 6 июля 2015 г (F). Нумерация возвратов соответствует нумерации в тексте. Фото М. Бабушкина.

White-Tailed Eagles ringed in the Darwin State Nature Reserve are returned to the Reserve in the following years: bird was ringed in 7 June 2014 (A) and March 2016 (B), bird was ringed in June 7 , 2014 (D) and was photographed by camera traps in 29 June 2015 (C), bird was ringed in 17 June 2013 (E) and was photographed by camera traps removed figure correspond to M. Babushkin. окольцованная 7 июня was observed in 29 in 6 July 2015 (F). Numbering of recoveries in those in text. Photos by
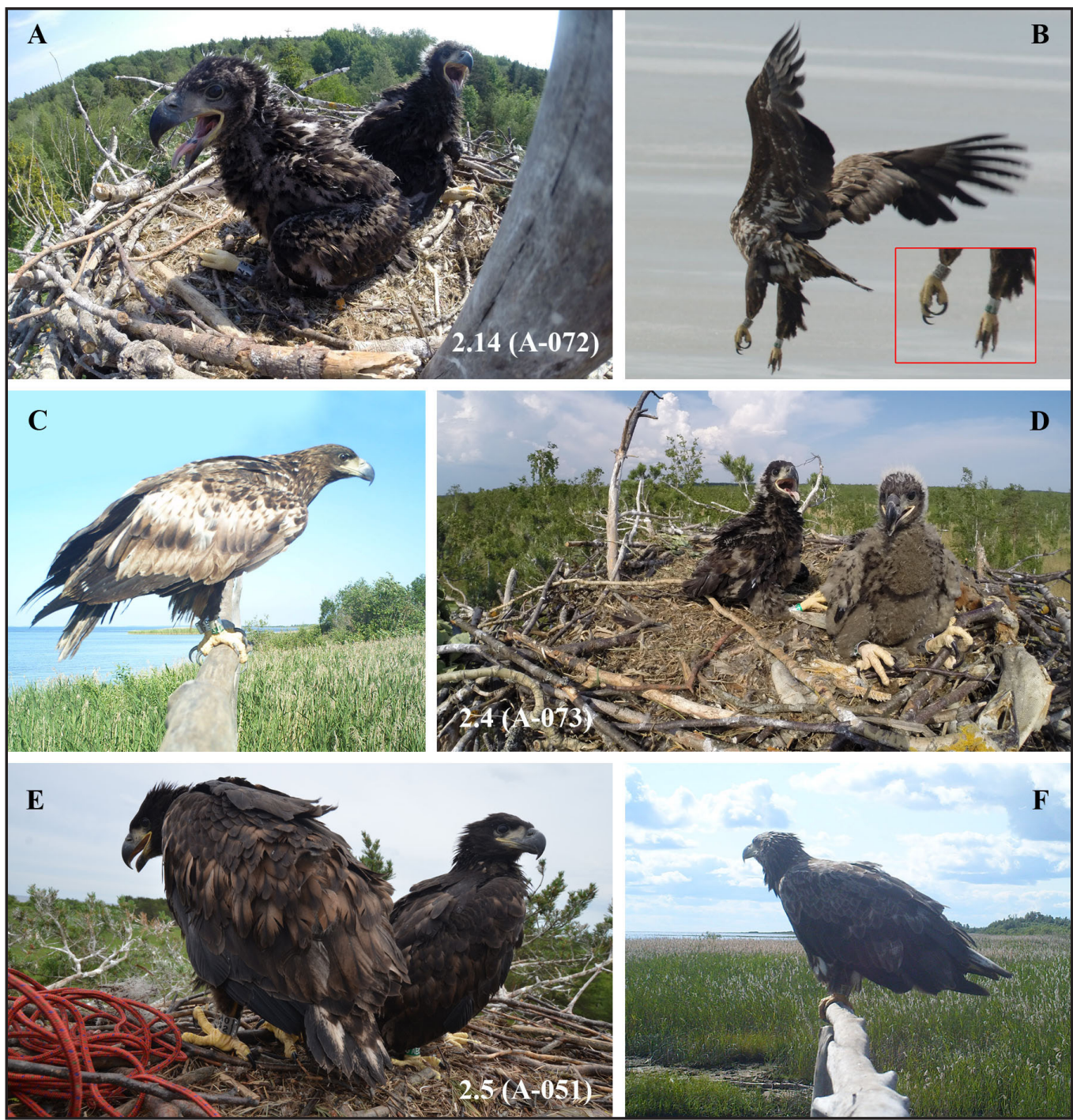

63 http://217.112.43.140/report/4226

67 http://217.112.43.140/report/4224

64 http://217.112.43.140/report/3203

68 http://217.112.43.140/report/3787

65 http://rrrcn.ru/forum/viewtopic.php?f=4\& $t=259 \# p 2102$

66 http://217.112.43.140/report/3072 


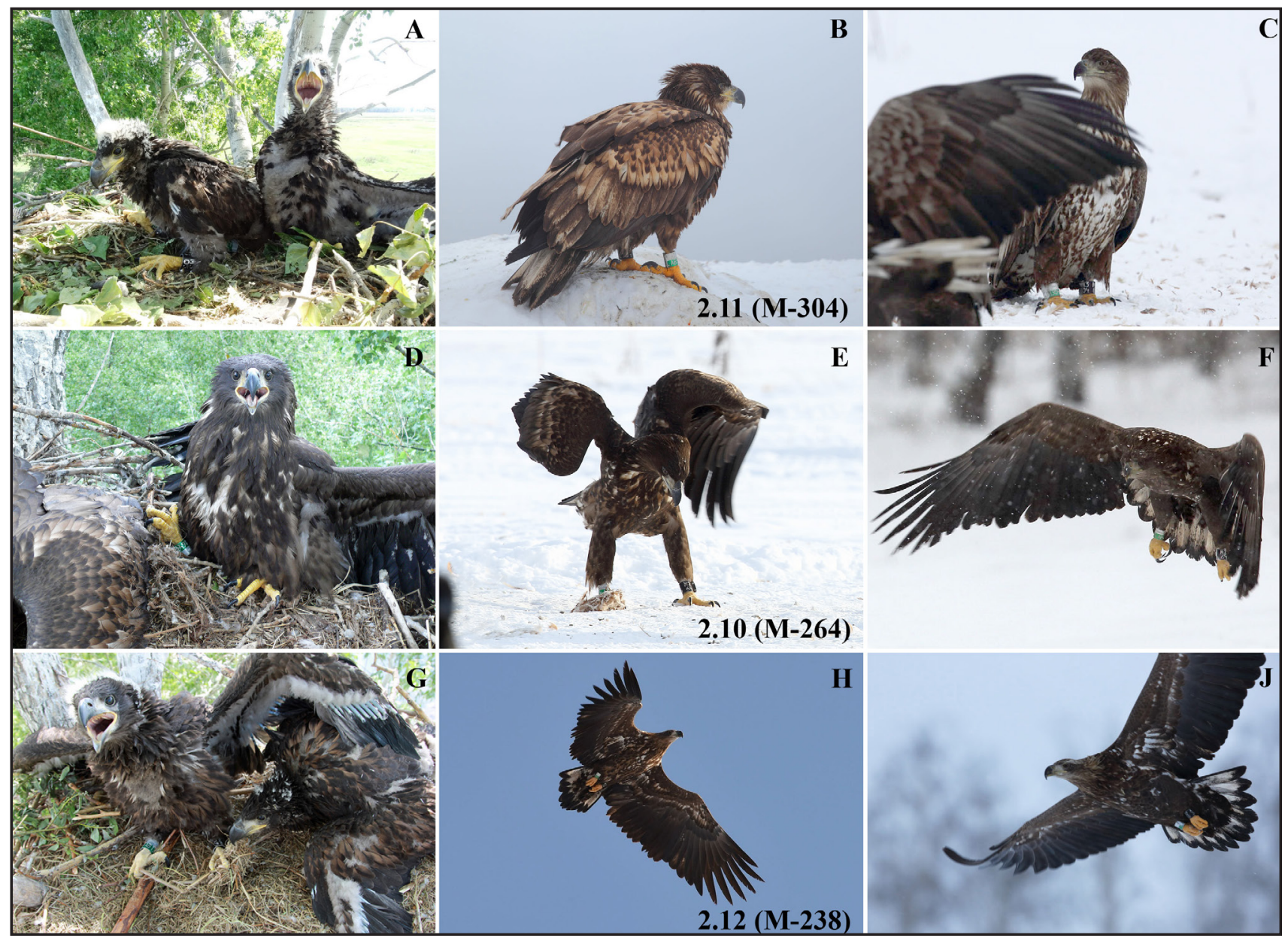

Орланы-белохвосты из Татарстана, регулярно зимуюшие под Ульяновском: птица, окольцованная 30 мая 2014 г. (А), встречена на зимовке 3 января 2015 г. (B) и 8 января 2016 г. (C), птица, окольцованная 20 июня 2013 г. (D), встречена на зимовке 2 февраия 2014 г. (E) и 8 января 2016 г. (F), птица, окольцованная 4 июня 2013 г. (G), встречена на зимовке 27 января 2015 г. (Н) и 8 января 2016 г. (J). Нумерация возвратов соответствует таковой в тексте. Фото Р. Бекмансурова, М. Тимофеева, Ф. Зелеева.

White-Tailed Eagles from Republic of Tatarstan are regular wintering near Ulyanovsk: bird was ringed in 30 May 2014 (A) was observed on wintering in 3 January 2015 (B) and 8 January 2016 (C), bird was ringed in 20 June 2013 (D) was observed on wintering in 2 February 2014 (E) and 8 January 2016 (F), bird was ringed in 4 June 2013 (G) was observed on wintering in 27 January 2015 (H) and 8 January 2016 (J). Numbering of recoveries in figure correspond to those in text. Photos by R. Bekmansurov, M. Timofeev and F. Zeleev.

на гнезде в Спасском районе Республики Татарстан 4 июня 2013 г. ${ }^{70} \Delta$ истанция - 133 км, азимут - 216 грацусов, продолжительность - 949 Аней (нескольким более 2,5 лет).

2.13. Орлан-белохвост (птенец), окольцованный Ринуром Бекмансуровым на гнезде 30 мая 2014 г. в Спасском муниципаиьном районе Республики Татарстан на территории Государственного природного заказника "Спасский" (номера колец АВ301 и М-301, средневолжская схема кольцевания) $)^{71}, 20$ марта 2016 г. отмечен на левобережье Волги к югу от г. Ульяновска. Птицу сфотографироваи Андрей Москвичёв ${ }^{72}$. Аистанция - 116 км, азимут - 212 градусов, продолжительность - 661 день (1 год и 10 месяцев $)^{73}$.
2.14. Орлан-белохвост (птенец), окольцованный Мирославом Бабушкиным 7 июня 2014 г. на гнезде в Аарвинском заповеднике (номера колец АВ-072 и А-072, схема мля Верхней Волги) ${ }^{\mathbf{7 4}}$, на второй гол жизни (29 марта 2016 г.) сфотографирован в натальной области на территории того же заповедника на побережье озера Изможево ${ }^{75}$. Автор наблюдения Мирослав Бабушкин. Аистанция - 14,8 км, азимут 281,6 градусов, продолжительность - 662 $\Delta$ Ня (почти 2 гоАа). ${ }^{76}$

2.15. Труп орлана-белохвоста с цветными кольцами 672 M-016 (цветовая схема Северо-Запаха России) обнаружен 4 апремя 2016 г. в Польше запаннее Белостока, между населёнными пунктами Аолистово
70 http://217.112.43.140/report/2069

71 http://217.112.43.140/report/3069

72 http://217.112.43.140/report/4389

73 http://rrrcn.ru/forum/viewtopic.php?f=4\& $t=294 \&$ start=10\#p2904
74 http://217.112.43.140/report/3615

75 http://217.112.43.140/report/4392

76 http://rrrcn.ru/forum/viewtopic.php?f=4\&t=294\& start=10\#p2930 
(Dolistowo) и Карповичи (Karpowicze) $)^{77}$. Причина гибели птицы не установлена. Coобшение получено через Российский центр кольцевания птиц. Этот орлан, будучи птенцом, 3 июня 2015 г. был окольцован Василием Пчелинцевым и Михаилом Шашкиным

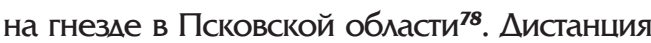
- 593 км, азимут - 211,5 грахусов, продолжительность - 307 Аней (около 1 года).

2.16. 28 мая 2016 г. во время мониторинга гнездования орлана-белохвоста в Республике Татарстан Ринур Бекмансуров сротограсрировая молодого орлана с цветными кольцами на лапах (средневолжская цветовая схема) ${ }^{79}$. Это третья летняя встреча молодой птицы в натамьной области.

\section{3. Орёл-могимьник (Aquila heliaca)}

3.1. Орёл-могильник (птенец), помеченный кольцами АА-2357 и В-67 (по схеме ммя
Аитае-Саянского региона) и спутниковым передатчиком ARGOS/GPS компании Microwave Telemetry, Inc. в гнезде на территории Алтайского края 20 июля 2014 г. $^{\mathbf{8 0}}$, обнаружен погибшим в натальной области (вернулся в места гнездования после успешной зимовки в Пакистане). Труп птицы был найден Сергеем Важов и Романом Бахтиным 5 августа 2015 г. $^{81}$ Орёл погиб, вероятно, в результате столкновения с проводами воздушной кинии электропередачи. Аистанция - 62 км, азимут - 240 грахусов, продолжительность жизни - 382 Аня (1 год). Подробная информация о миграции этого орла-могильника доступна на сайте $^{82}$ и форуме ${ }^{83}$ Российской сети изучения и охраны пернатых хишников.

3.2. Орёл-могильник (птенец), помеченный (кольца АВ-0201-0С и В-201 по схеме мля Волго-Ураиьского региона) 20 июля

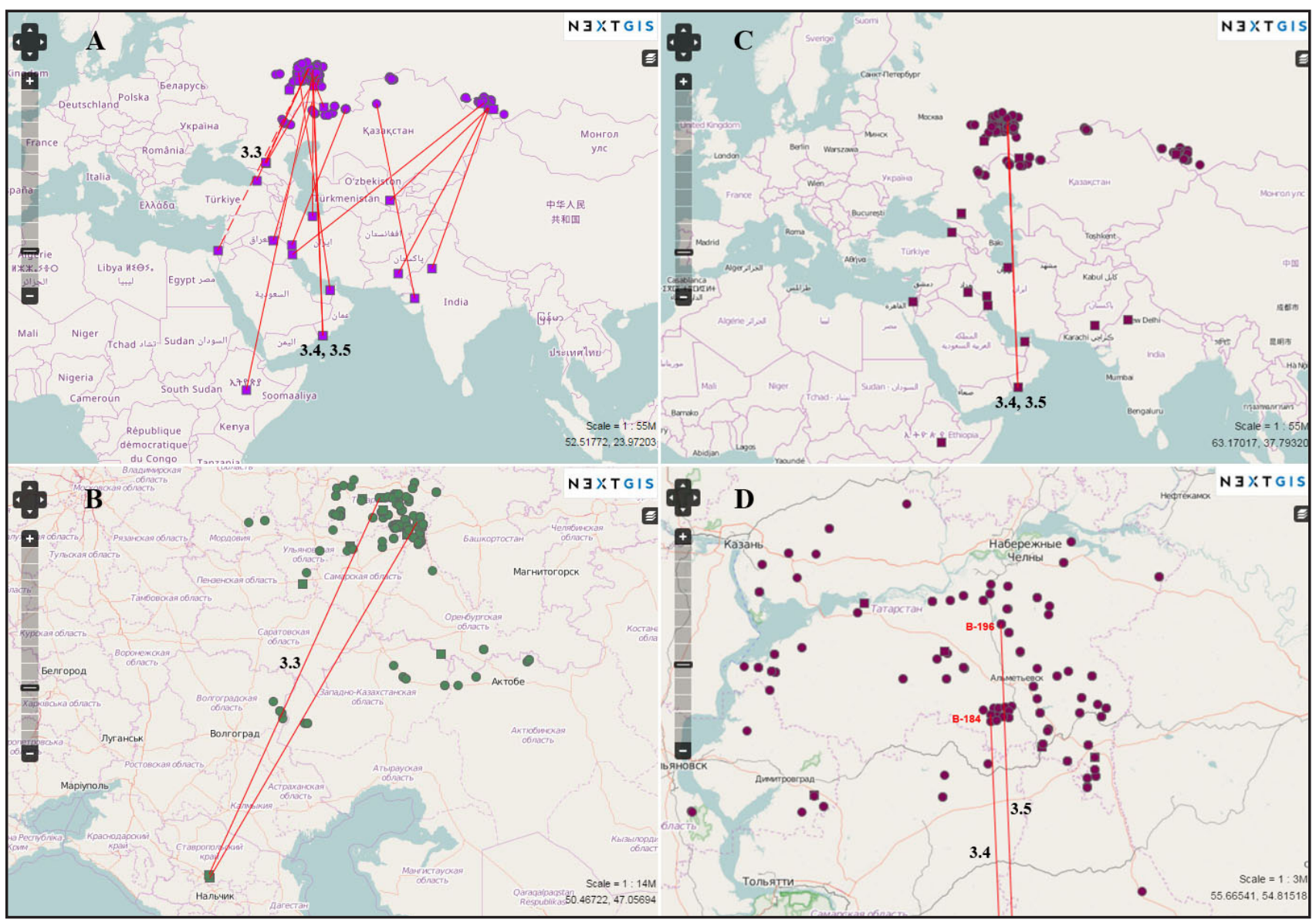

Pис. 6. Ааиьние возвраты орлов-могильников (Aquila heliaca), полученные в ходе работы программы кольцевания Российской сети изучения и охраны пернатых хищников: все возвраты - A, возвраты татарских орлов из Ставропольского края - В, возвраты татарских орлов из Омана - C и D. Нумерация возвратов соответствует нумерации в тексте.

Fig. 6. Long distance recoveries of the Imperial Eagle (Aquila heliaca), obtained in the course of the work Colour Ringing Programme of the Russian Raptor Research and Conservation Network: all recoveries - A, Tatarian eagle recoveries from Stavropol Kray - B, Tatarian eagle recoveries from Oman $-C$ and $D$. Numbering of recoveries in figure correspond to those in text.

\footnotetext{
77 http://217.112.43.140/report/4407

$81 \quad$ http://217.112.43.140/report/3882

78 http://217.112.43.140/report/3978

82 http://rrrcn.ru/migration/eagles2014/7

79 http://rrrcn.ru/forum/viewtopic.php?f=4\& $t=294 \&$ start=20\#p3054 83 http://rrrcn.ru/forum/viewtopic.php?f=4\& $t=232$

so http://217.112.43.140/report/3552
} 
Миачший птенец орламогильника (слева), окольцованный 10 июля 2015 года на гнезце в Лениногорском районе Республики Татарстан (Россия), сфотографирован 28 ноября 2015 г. на сваике в Рейсуте (Саиала, $\triangle$ хосрар, Оман) (внизу справа). Фото Р. Бекмансурова и А. Пая.

Junior nestling of the Imperial Eagle (at the left) was ringed in 10 July 2015 at Leninogorsk in the nest area of the Republic of Tatarstan (Russia), and was photographed in the dump Reysute (Salalah, Dhofar, Oman) in 28 November 2015 (bottom at the right). Photos by

R. Bekmansurov and A. Pai
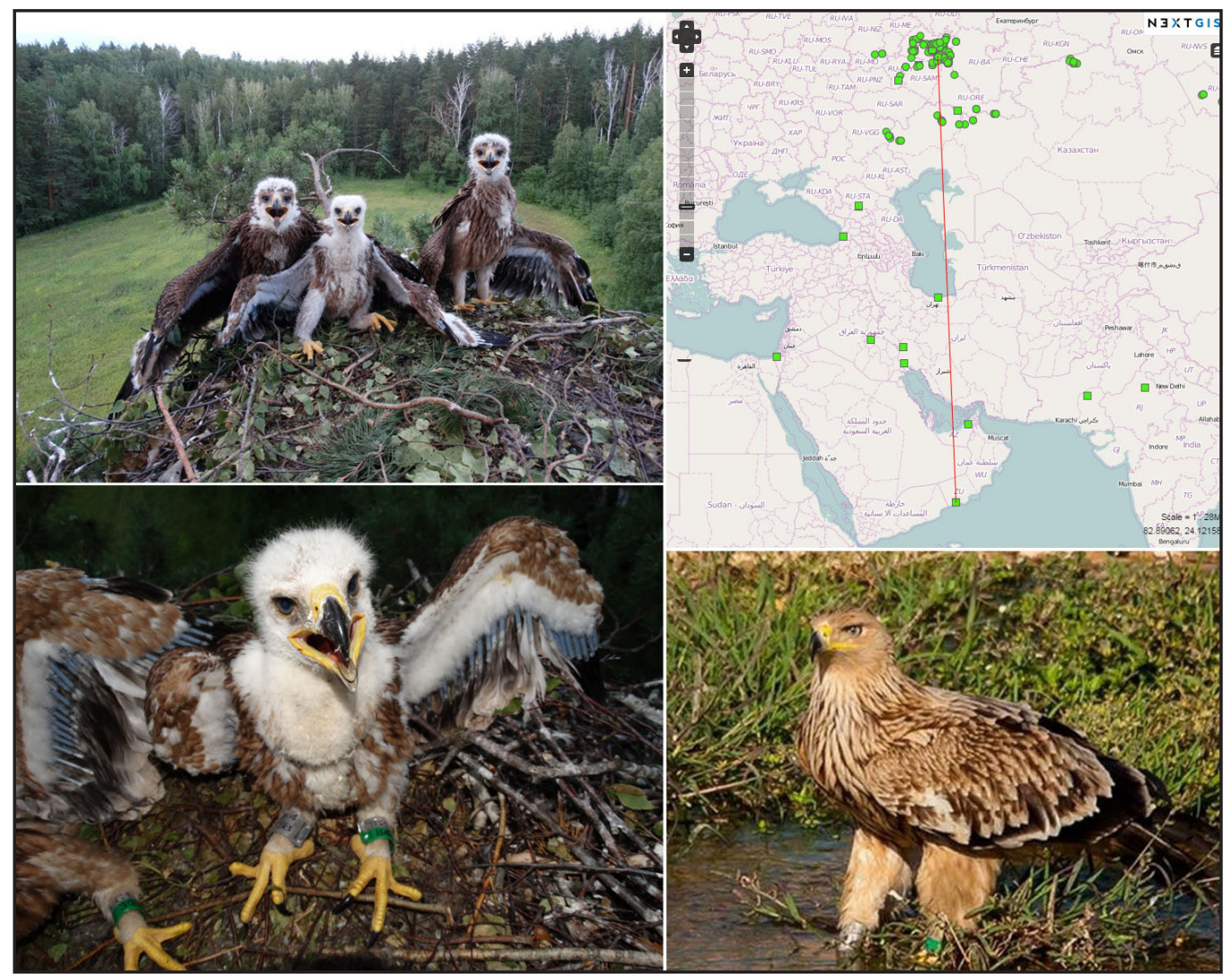

2015 г. Ринуром Бекмансуровым на гнез-

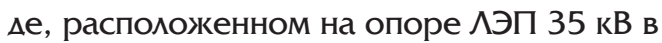
Аиьметьевском районе Республики Татарстан $^{84}$, в августе 2015 г. (точная дата неизвестна) обнаружен мёртвым на окраине г. Аиьметьевск ${ }^{85}$. Мёртвого орла обнаружил начальник районного отлела по Альметьевскому муниципальному району Управления по охране и использованию объектов животного мира Республики Татарстан - Муртазин Айдар Гумарович. Труп лежам поА опорой АЭП 10 кВ со штыревыми изомяторами, не зашишёнными специальными птицезашитными устройствами. Аапы птицы обгоревшие. Труп птицы в состоянии разложения. Аистанция - около 11,7 км, азимут - около 244 градуса от гнезда, продолжительность жизни - не более 25 $\Delta$ ней $^{86}$.

3.3. Миацший птенец (один из Авух) орла-могильника (самец), помеченный (кольца АА-2919 и В-73 по схеме мля Волго-Ураиьского региона) Ринуром Бекмансуровым 14 июля 2013 г. в Нижнекамском районе Республики Татарстан близ с. Камские Поляны $^{87}$, спустя 2 года 3,5 мес. (31 октября 2015 года) попал в старую сетку в 120 м от ассральтированной дороги и в 800 м от станицы Незлобной Георгиевского района Ставропольского края (в 30 км от аэропорта Минеральные воды), откуда был извлечён и отпушен на волю Юрием Крячко, о чём сообшила Аюбовь Маловичко ${ }^{88,89}$. Аистанция - 1368 км, азимут 207,6 градусов, продолжительность - 840 $\Delta$ ней.

3.4. Миацший из 3-х птенцов могильника, помеченный Ринуром Бекмансуровым цветными кольцами (АВ-0184-8B, В-184 по схеме мия Волго-Ураиьского региона) 10 июля 2015 года на гнезде в Лениногорском районе Республики Татарстан близ с. Федотовка90, появился в поле зрения фотограсов почти через 5 месяцев после кольцевания. Ашутош Пай (Ashutosh Pai) 28 ноября 2015 г. сфотограсрироваи этого молодого могильника на сваике в Рейсуте (Салала, Ахосрар, Оман) ${ }^{\mathbf{1 1}}$. О встрече сообшили Виктор Реджинамьд (Reginald Victor) и Майк МакГрахи (Mike McGrady). Аистанция - 4184 км, азимут - 177 градусов, продолжительность - 142 Аня. Это первый возврат орла-могильника из Омана ${ }^{92}$. $\Delta$ о этого отсюда же было 2 возврата степных орлов.

\footnotetext{
84 http://217.112.43.140/report/4169

85 http://217.112.43.140/report/4396

86 http://rrrcn.ru/forum/viewtopic.php?f=4\& $t=259 \&$ start=90\#p2965

87 http://217.112.43.140/report/2191

s8 http://217.112.43.140/report/4063

$\begin{array}{ll}\text { 89 } & \text { http://rrrcn.ru/forum/viewtopic. } p h p ? f=4 \& t=259 \& \text { start=60\#p2725 } \\ \text { 9o } & \text { http://217.112.43.140/report/4057 } \\ \text { 91 } & \text { http://217.112.43.140/report/4135 } \\ \mathbf{9 2} & \text { http://rrrcn.ru/forum/viewtopic.php?f=4\& } t=259 \& \text { start=60\#p2734 }\end{array}$
} 
$\triangle$ анное наблюдение также важно мля понимания успеха размножения и выкармиивания парой птиц всех 3-х птенцов.

3.5. Самка орла-могильника (средняя по возрасту в выводке из 3-х птенцов) была помечена Ринуром Бекмансуровым по схеме мия Волго-Ураиьского региона (номера колец АВ-0196-9В и В-196) 19 июля 2015 г. в гнезде близ г. Заинск (Республика Татарстан) ${ }^{93}$. Птица обнаружена умираюшей, вероятно, в результате отравления, 29 хекабря 2015 г. на месте крупной зимовки орлов в Омане. Сообшил об этом Салем Аль Машани (Salem A Al Mashani) ${ }^{94}$. Позднее, уже в ветлечебнице, птица умерма. Аистанция - 4251 км, азимут - 177 граАусов, продолжительность - 164 Аня. Это второй возврат орла-могильника из Омана в оАИн гоА из оАной и той же гнезАовой группировки в Татарстане ${ }^{95}$.

3.6. Самка орла-могильника (птенец) была помечена международной российско-венгерской командой под руководством Игоря Карякина и Эльвиры Николенко 17 июля 2014 г. в Усть-Канском районе Республики Алтай (Россия) кольцами АВ-0116-1А и В-116 по схеме мия Аитае-Саянского региона и GSM/GPS

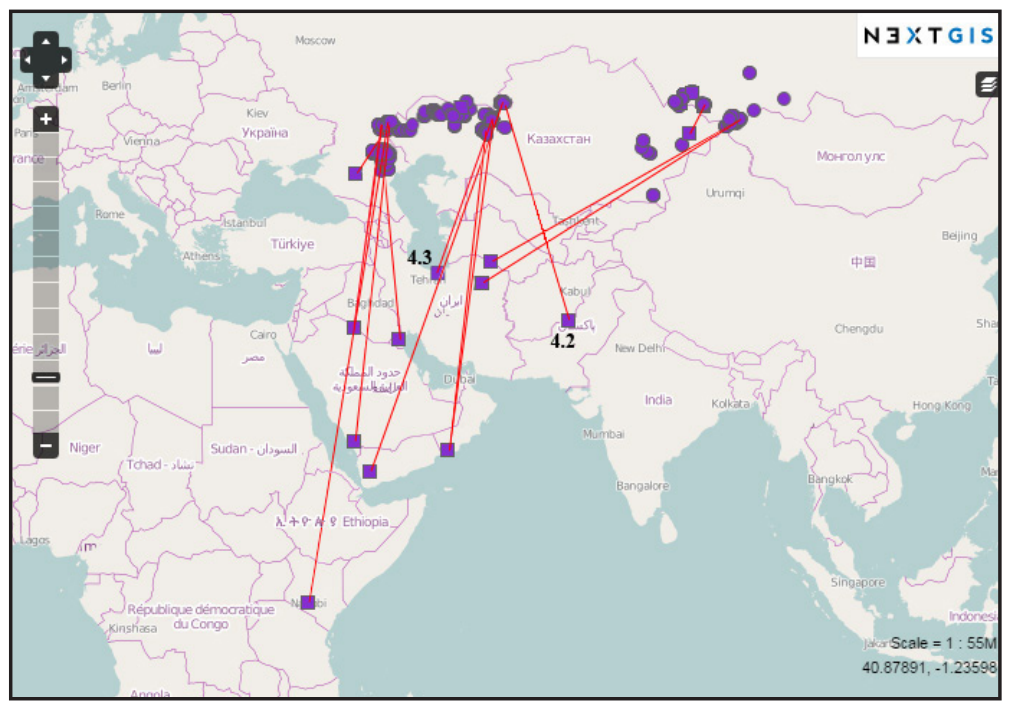

Рис. 7. Ааиьние возвраты степных орлов (Aquila nipalensis), полученные в ходе работы программы кольцевания Российской сети изучения и охраны пернатых хищников. Нумерация возвратов соответствует нумерации в тексте.

Fig. 7. Long distance recoveries of the Steppe Eagle (Aquila nipalensis), obtained in the course of the work Colour Ringing Programme of the Russian Raptor Research and Conservation Network. Numbering of recoveries in figure correspond to those in text. передатчиком польской фрирмы Экотон ${ }^{96}$. Птица погибла в результате поражения

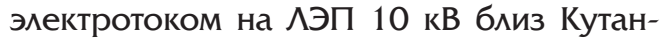
бая Кашкамарьинской области в Узбекистане 19 февраля 2016 г. Засвидетельствовал факт гибели птицы Аенис Чои 25 февраля 2015 г. ${ }^{97}$ Аистанция - 1957 км, азимут - 234 градуса, продолжительность - 583 Аня (1,5 года с небольшим). Подробная инсормация о миграции этого орла-могильника доступна на сайте 98 и форуме ${ }^{99}$ Российской сети изучения и охраны пернатых хишников.

\section{4. Степной орё^ (Aquila nipalensis)}

4.1. Птенец степного орла (самка) помечен Игорем Карякиным и Людмилой Зиневич 7 июля 2015 г. в Акбулакском районе Оренбургской области между сёлами Шкуновка и Новоуспеновка (кольцами АВ0215-1С и В-215 по схеме Волго-Урамьского региона) ${ }^{100} .24$ августа 2015 г. пришло сообшение от респондента Ирины из Акбулака об обнаружении трупа этой птицы, сбитой машиной на автодороге на расстоянии не далее 1 км от гнезАа ${ }^{101}$. Птица прожила всего 49 дней. В Аанной местности численность степного орла сушественно сократилась после 2010 года, и до посленнего времени здесь сохранялось единственное жилое гнезАо степных орлов ${ }^{102}$.

4.2. Степной орёл (птенец), окольцованный Игорем Карякиным и ЛюАмилой Зиневич 3 июля 2015 г на гнезде в Оренбургской области (номера колец АА-0169-6В, С-170, цветовая схема мяя Волго-Уральского региона) ${ }^{103}$, был отловлен в период миграции с целью продажи 26 сентября 2015 г. Место отлова: Какар Хурасан Тешил в районе Кима-Сайфумла, Белуджистан, Пакистан ${ }^{104}$. Аистанция - 2276 км, азимут - 160,4 грахуса, продолжительность - 86 Аней. Аамьнейшая судьба птицы неизвестна ${ }^{105}$ (Карякин и Ар., 2016).

4.3. Степной орёл (старший птенец в выводке), окольцованный Игорем Карякиным 29 июня 2015 г. на гнезде в Актюбинской области Казахстана в районе Копы ${ }^{106}$, обнаружен погибшим 14 ноября 2015 г. в Иране в горах южнее Каспийского моря) ${ }^{107}$. Респонденты: Ашгар Мохаммахи (Asghar Mohammadi) и Корос Рбие (Koros Rbiee.

\footnotetext{
93 http://217.112.43.140/report/4156

94 http://217.112.43.140/report/4214

95 http://rrrcn.ru/forum/viewtopic.php?f=4\& $t=259 \&$ start $=80 \# p 2823$

96 http://217.112.43.140/report/3512

97 http://217.112.43.140/report/4310

98 http://rrrcn.ru/migration/eagles2014/4

99 http://rrrcn.ru/forum/viewtopic.php?f=4\& $t=230$

100 http://217.112.43.140/report/3899
}

\author{
101 http://217.112.43.140/report/3901 \\ 102 http://rrrcn.ru/forum/viewtopic.php?f=4\& $t=259 \&$ start $=30 \# p 2437$ \\ 103 http://217.112.43.140/report/3908 \\ 104 http://217.112.43.140/report/3909 \\ 105 http://rrrcn.ru/forum/viewtopic. php?f=4\& t=259\&start=40\#p2585 \\ 106 http://217.112.43.140/report/4201 \\ 107 http://217.112.43.140/report/4203
}




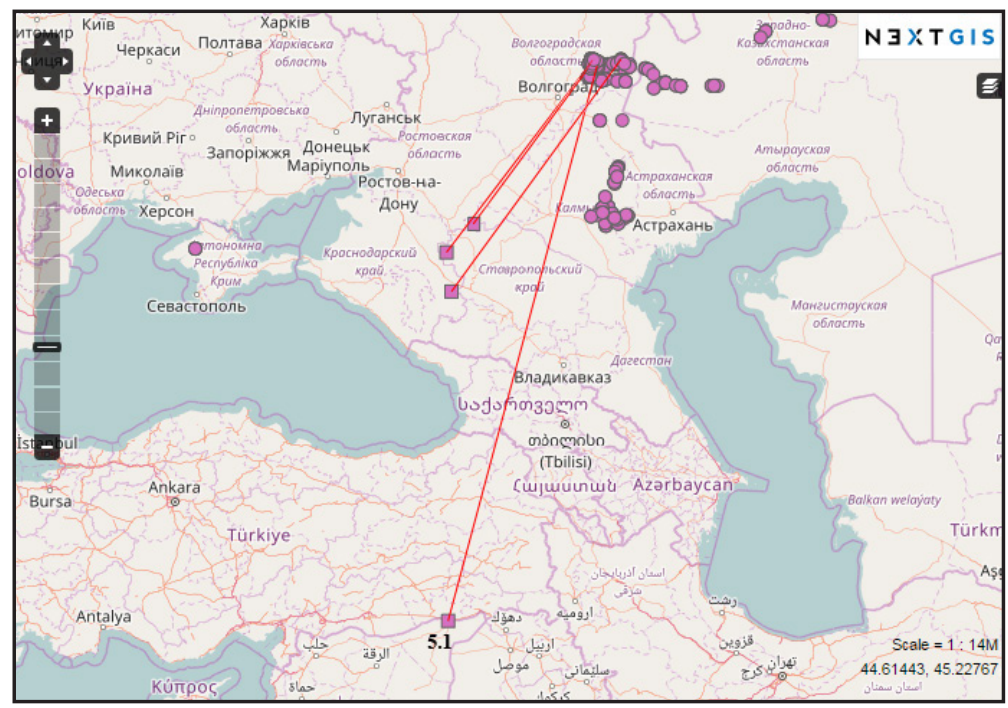

Рис. 8. Аальние возвраты курганников (Buteo rufinus), полученные в ходе работы программы кольцевания Российской сети изучения и охраны пернатых хишников. Нумерация возвратов соответствует нумерации в тексте.

Fig. 8. Long distance recoveries of the Long-Legged Buzzards (Buteo rufinus), obtained in the course of the work Colour Ringing Programme of the Russian Raptor Research and Conservation Network. Numbering of recoveries in figure correspond to those in text.

Причина гибели не установлена. Степной орёл носил кольца ВК-1493-9S и С-353 схемы Запанного Казахстана. Аистанция 1612 км, азимут - 202 грахуса, продолжительность жизни - 139 Аней ${ }^{108}$.

4.4. Птенец степного орла, окольцованный Игорем Карякиным и Людмимой Зиневич 4 июля 2015 г. на гнезде в Оренбургской области (кольцо АА0281-8C) ${ }^{109}$ подран четвероногим хищником. Птица была изъята из природной среды 5 июля 2015 г. и направлена на лечение и реабилитацию в РЗОО «Симбирский центр спасения Аиких животныХ" в г. УАьяновск ${ }^{110}$.

\section{5. Курганник (Buteo rufinus)}

5.1. Курганник (птенец, один из 4-х птенцов в выводке), окольцованный Валерием Пименовым и Михаилом Байбаковым 5 июня 2014 г. на гнезде в Волгограхской области к западу от Булухты ${ }^{111}, 7$ октября 2015 г. был вырван из лап орла в Сирии на границе Турции и Сирии в г. Эль-Камышлы ${ }^{12}$. Птица носила кольца BS005944 и D-44 схемы мя Нижней Волги. Сообшение прислам Немер Аласи (Nemer Alasi). Курганник погиб. Аистанция -
1413,5 км, азимут - 196,7 грауусов, срок жизни - 490 дней (1 год 3 мес. и 2,5 неА.).

\section{Cancah (Falco peregrinus)}

6.1. Ринуром Бекмансуровым 11 июня 2015 г. в гнезде на северо-востоке Татарстана пластиковым кольцом D-23 помечен один из 4-х птенцов сапсана ${ }^{113}$. В августе этого же года птица погибла в г. Чистополь Республики Татарстан ${ }^{14}$. Полные обстоятельства её гибели неизвестны. Сообшили, что птица разбилась, ударившись о препятствие. Но, скорее всего, её убили при попытке охоты на Аомашних голубей возме частной голубятни. Аистанция - 93 км, азимут - 246 градусов, продолжительность жизни - 76 Аней ${ }^{115}$.

6.2. На территории Южно-Ураиьского государственного природного заповедника в Республике Башкортостан 6 июня 2015 г. Валерием Алексеевым были окольцованы Ава птенца сапсана. При проверке этого же гнезда 5 августа 2015 г. были обнаружены останки 2-х птенцов с кольцами D-73 и D-74 (красные кольца с белым кодом) растерзанных срилином (Bubo bubo) ${ }^{116,117}$.

\section{Возвраты российских птиц, поме- ченных в рамках Аругих проектов \\ 7. Cancah (Falco peregrinus)}

7.1. Сапсан (петнец), окольцованный в рамках программы IWC на Ямале (кольца В-430039 и К-5 красное с белым кодом) 26 июля 2015 г. $^{118}, 2$ ноября 2015 г. отловлен с целью продажи на побережье Аивии близ Аиь Магруна примерно в 70 км к юго-юго-западу от Бенгази ${ }^{119}$. Аистанция - 5153 км, азимут - 243 грахуса, проАОлжительность - 98 Аней ${ }^{120}$.

7.2. Сапсан (птенец), помеченный в рамках программы IWC на Ямале близ с. Еркута (кольца DS-013019 и L-4 красное с белым коАОм) 27 июля 2015 г. ${ }^{121}$, был отловлен в Ираке 2 декабря 2015 г., о чём сообщил Аиьбара Бинозман (Albara Binothman)122. Аистанция - около 4160 км, азимут - около 214,5 грацусов, продолжительность - 129 Аней ${ }^{123}$.

\section{8. Орлан-белохвост \\ (Haliaeetus albicilla)}

8.1. Взрослый орлан-белохвост, имеюший цветные кольца на обеих мапах, был \begin{tabular}{ll}
\hline $\mathbf{1 0 8}$ & http://rrrcn.ru/forum/viewtopic.php?f=4\&t=259\&start=70\#p2786 \\
109 & http://217.112.43.140/report/4628 \\
$\mathbf{1 1 0}$ & http://217.112.43.140/report/4629 \\
$\mathbf{1 1}$ & http://217.112.43.140/report/3720 \\
$\mathbf{1 1 2}$ & http://217.112.43.140//report/3970 \\
$\mathbf{1 1 3}$ & http://217.112.43.140/report/3911 \\
$\mathbf{1 1 4}$ & http://217.112.43.140/report/3915 \\
$\mathbf{1 1 5}$ & http://rrcn.ru/forum/viewtopic.php?f=4\&t=259\&start=40\#p2619
\end{tabular}
116 http://217.112.43.140/report/3827

117 http://217.112.43.140/report/3828

118 http://217.112.43.140/report/4174

119 http://217.112.43.140/report/4055

120 http://rrrcn.ru/forum/viewtopic. php?f=4\& t=259\&start=60\#p2723

121 http://217.112.43.140/report/4182

122 http://217.112.43.140/report/4181

123 http://rrrcn.ru/forum/viewtopic.php?f=4\& $t=259 \&$ start=70\#p2775 
Рис. 9. Возвраты тунАровых сапсанов (Falco peregrinus calidus) $\boldsymbol{B}$ 2015 г.: птица, пойманная в Ираке - A, В, схема возвратов - C (нумерация возвратов соответствует нумерации в тексте), схема возвратов микрочипов и треки мигрировавших птиц, помеченных спутниковыми передатчиками - D (из: Sokolov et al., 2016).

Fig. 9. The Tundra Peregrine Falcon (Falco peregrinus calidus) recoveries in 2015: bird trapped in Iraq $-A$, $B$, recovery schemes - $C$ (numbering corresponds to that of the return in the text), recovery schemes of the microchips and routes of migrating birds tagged with satellite transmitters $-D$ (from: Sokolov et al. 2016).

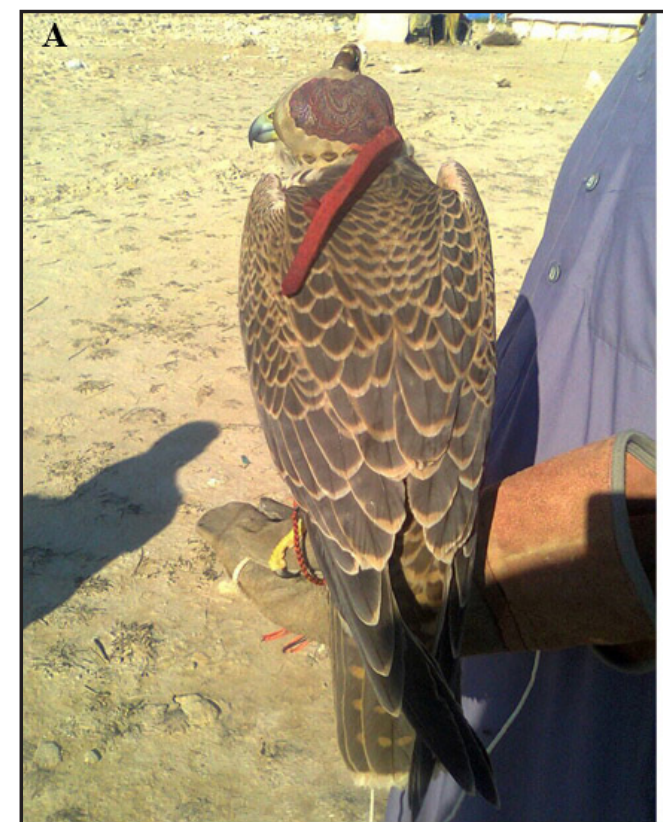

B

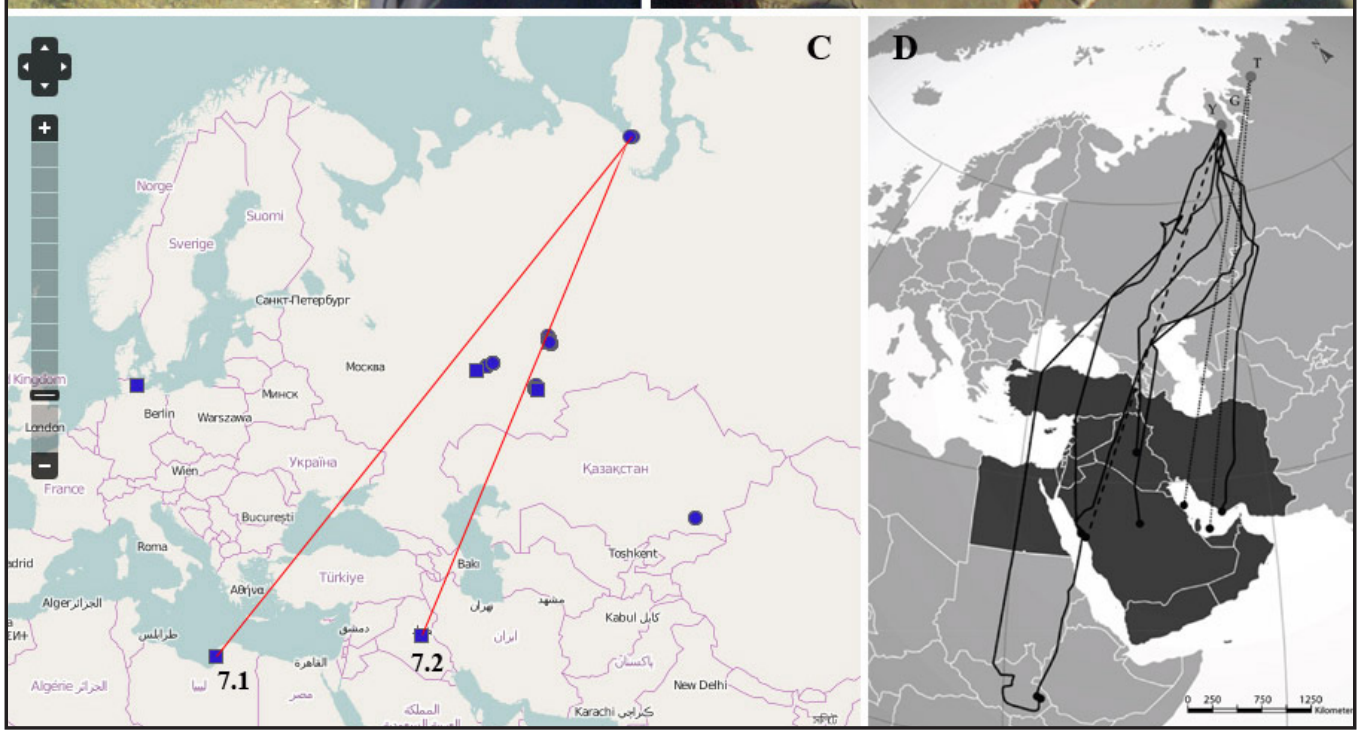

сротограсирован 25 сентября 2015 г. Сергеем Плыткевичем в окрестностях озера Нечерица в Себежском районе Псковской области. О наблюдении сообшил $\triangle$ енис Китель ${ }^{124}$. Птица была помечена по европейской программе кольцевания орланов - кольцо региона + кольцо года, что позволяло предполагать её эстонское, либо белорусское происхожление. ВлаАимир Ивановский пометил такими кольцами 4-х орланов. Весьма вероятно, что это один из Авух орланов, окольцованных 3 июня 1988 года в гнезде, находившемся межлу озёрами Осыно и Нечерица Псковской области. Кольца, обозначавшие регион, имели налпись MOSCOW и номера 005 и 006 125 . Окончательную точку в илентисикации колец поставить не уда- мось, как собственно под вопросом остался и возраст птицы. Но если эта птица была окольцована В. Ивановским, то она встречена на расстоянии всего 9 км от места своего рождения через 27 лет!

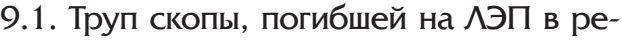
зультате поражения электротоком, обнаружен в Псковской области 4 июля 2015 г. Василием Пчелинцевым и Мариной Силенко ${ }^{126}$. Птица носила метамическое кольцо M-62278 Helsinki Museum и была окольцована 14 июля 2012 г. в Финляндии ${ }^{127}$. Аистанция - 349 км, азимут - 179 грахусов, продолжительность - 1086 Аней (3 года) $)^{\mathbf{1 2 8}}$.

9.2. В Псковской области исследовате-

\section{Возвраты зарубежных птиц в России 9. Скопа (Pandion haliaetus)}

\footnotetext{
124 http://rrrcn.ru/forum/viewtopic.php?f=4\& t=259\&start=60\#p2732 


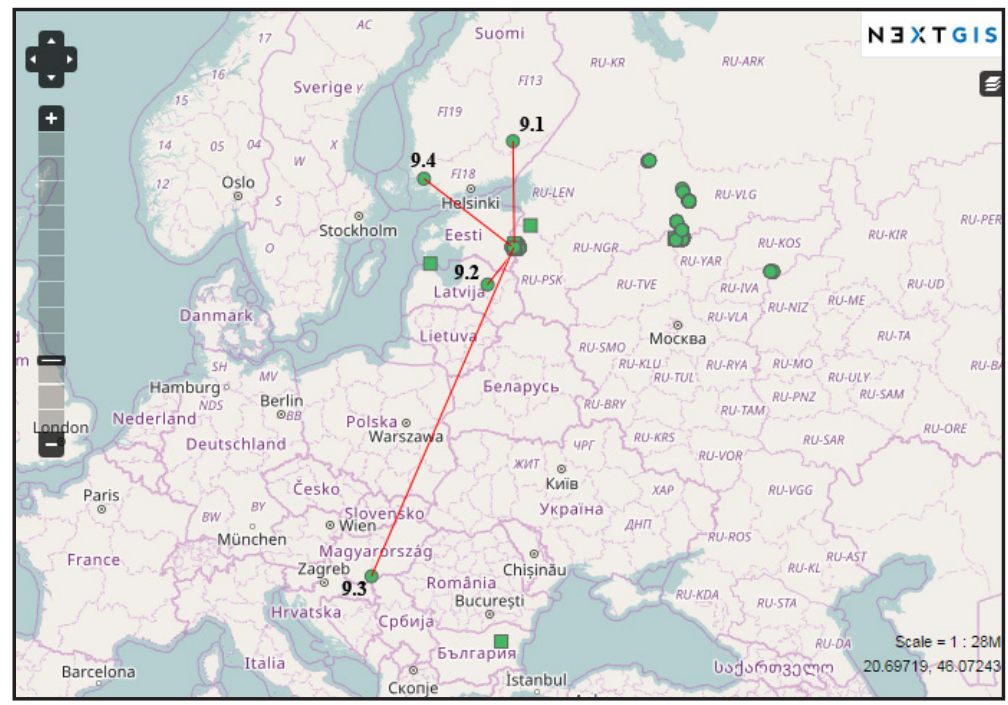

ли Гуннар Сейн (Sein Gunnar) и Михкелем ТийАо (Mihkel Tiido) во время осмотра гнезда скопы 12 июля 2015 г. сфотографрироваяи размножаюшуюся на этом гнезме самку с кольцом С-08 красного цвета с белым кодом ${ }^{129}$. По инсормации, предоставленной Аатвийским центром кольцевания, выяснилось, что данная скопа была помечена птенцом на гнезде в Латвии 30 июня 2009 г. ${ }^{130} \Delta$ истанция - 167 км, азимут - 37,6 градусов, продолжительность 2204 Аня (6 лет) ${ }^{131}$.

9.3. Скопа (взрослая самка), размножаюшаяся в известном гнезде в Псковской области, отловлена 14 июля 2015 г. на своём гнездовом участке с целью Аополнительного кольцевания группой исследователей под руководством Василия Пчелинцева ${ }^{132}$. Птица носила метамическое кольцо KS00841 Budapest. Согласно данным Венгерского центра кольцевания птиц, эта скопа была отловлена и окольцована 10 апреля

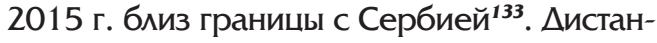
ция - 1483 км, азимут - 20,6 грацусов, проАолжительность - 96 Аней ${ }^{134}$.

9.4. Скопа (взрослая самка), отловленная 15 июля 2015 г. группой исследователей под руководством Василия Пчелинцева в Псковской области, носила метамическое кольцо M-38546 Helsinki Museum ${ }^{135}$. Птица была окольцована 12 июля 1997 г. в районе Аландских островов в ФинлянАии ${ }^{\mathbf{1 3 6}}$. Аистанция - 398 км, азимут - 125 градусов, продолжительность - 6578 дней $(18 \text { лет! })^{134}$.
Рис. 10. Возвраты от зарубежных скоп в России. Нумерация возвратов соответствует нумерации в тексте.

Fig. 10. The Osprey recoveries from the foreign countries in Russia. Numbering of recoveries in figure correspond to those in text.

\section{0. Орлан-белохвост (Haliaeetus albicilla)}

10.1. 18 октября 2015 г. найдены останки орлана-белохвоста на берегу реки Синей Красногородского района Псковской области. Причина гибели неизвестна. Автор наблюдения Федоров Вячеслав Влачимирович ${ }^{137}$. По кольцам на птице 39 D4 (чёрное снизу и красное сверху с белым кодом) и N-2952 (чёрное с белым кодом) с аббревиатурой RIKSMUSEUM STOCKHOLM SWEDEN, установлено, что птицу окольцеваи Бьорн Хеландер (Bjorn Helander) 6 июня 2011 года к юго-востоку от города Остхаммар (Цsthammar) в грасстве Уппланд (Швеция) ${ }^{138}$. Аистанция - 680 км, азимут - 120 грацусов, продолжительность - 1596 Аней (4 года и 3 месяца) ${ }^{139}$.

\section{Возвраты зарубежных птиц за пределами России}

11. Большой подорлик (Aquila clanga)

11.1. Большой подорлик, родом со СреАней Припяти из-под Аавид-Городка (Белоруссия), окольцованный 17 июля 2012 года интернациональной командой под руководством Валерия Аомбровского ${ }^{140}$, уже трижАы отметился в Израиле. Птица носит кольцо из пластика синего цвета с номером D-6 и метамическое кольцо серебристого цвета - ВА-0459. Первый возврат был получен 18 октября 2012 г. ${ }^{141}$ Тогла птица попалась в мовушку мля ворон в окрестностях Тель-Авива. Её Аоставили в Израильский реабилитационный центр, гле было констатировано её хорошее физическое состояние. Подорлика выпустили на волю в месте поимки. ОАнако 12 феврачя 2013 г., то есть через 4 месяца, этот поАорлик снова оказался в руках израильских орнитологов. На этот раз он попался в орнитологическую сеть приблизительно в том же месте, что и в прошлый раз. Третий раз этого подорлика удалось ссото-

\footnotetext{
129 http://217.112.43.140/report/4419

130 http://217.112.43.140/report/4420

131 http://rrrcn.ru/forum/viewtopic.php?f=4\& $t=259 \&$ start=100\#p3151

132 http://217.112.43.140/report/4397

133 http://217.112.43.140/report/4411

134 http://rrrcn.ru/forum/viewtopic. $p h p ? f=4 \& t=259 \&$ start $=100 \# p 3155$

135 http://217.112.43.140/report/4332
}

\author{
136 http://217.112.43.140/report/4410 \\ 137 http://217.112.43.140/report/3997 \\ 138 http://217.112.43.140/report/3996 \\ 139 http://rrrcn.ru/forum/viewtopic.php?f=4\& $t=259 \&$ start $=50 \# p 2706$ \\ 140 http://217.112.43.140/report/1384 \\ 141 http://217.112.43.140/report/1385
}




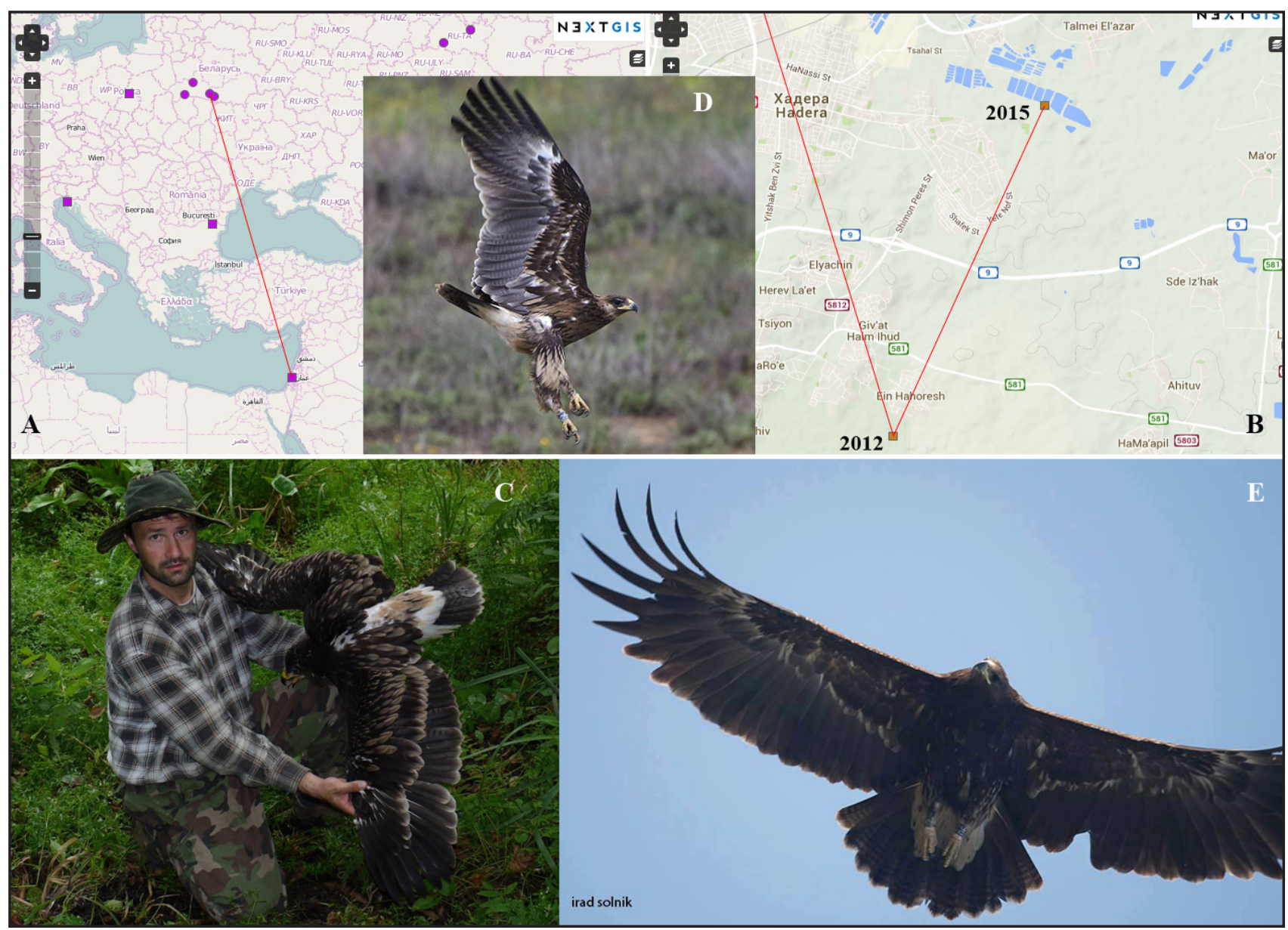

Рис. 11. Схема возвратов от белорусского большого подорлика (Aquila clanga) $-A, B$, он же во время кольцевания в Беларуси 17 июля 2012 года - С, на зимовке в Израиле 18 октября 2012 г. - D и 29 ноября 2015 г. - E. Фото В. Аомбровского и И. Солника.

Fig. 11. The Belarusian Greater Spotted Eagle (Aquila clanga) recoveries in Israel $A, B$, while ringing in Belarus in 17 July 2012 - C, on wintering in Israel in 18 October $2012-D$ and 29 November 2015 - E. Photos by V. Dombrovsky and I. Solnik. грасировать Ираху Солнику (Irad Solnik) 29 ноября 2015 г. всего в 6,5 км от преАылуших мест поимок, на берегу рыбоводных прудов. ${ }^{142}$ Аистанция - 2275 км, азимут - 160,7 градусов, продолжительность жизни - 1231 день (3 года и 4 месяца). ${ }^{143}$

11.2. Большой подорлик (птенец), помеченный (пара цветных колец 2В) Гжегошем Мациоровским (Grzegorz Maciorowski) 14 июля 2015 г. в Бебжанском нацпарке в Польше ${ }^{\mathbf{1 4 4}}$, встречен Рэми Замиром (Ramy Zamir) 16 января 2016 г. в Израиле близ кибуца Маоз Хаим (Maoz Haim) ${ }^{145}$. Аистанция - 2549 км, азимут - 151,5 грахусов, продолжительность жизни - 187 Аней (полгоАа) $)^{146}$.

\section{ОбсужАение}

Мечение хишных птиц цветными кольцами вновь продемонстрировало своё преимушество в идентисрикации птиц в природе. Благодаря этому методу за отчётный период в природе сфотограсировано различными наблюдателями 27 птиц с цветными кольцами (65 \% от всех возвратов, рис. 12), вкАючая 4 птицы, сфотограсрированные с помошью специально установленных фотоловушек. Из них идентисицирована 21 птица (скопа - 8, орлан-белохвост - 11 , орёл-могильник - 1, большой подорлик - 2), а мия 5 орланов по цветам колец определены регионы кольцевания. Регистрации живых птиц в природе - это самые приятные сообшения. По ним вновь видна география работы бёдвотчеров. Инсормация о фотонаблюдениях поступила из таких зарубежных стран, как Болгария, Кипр, Мозамбик, Камерун, ЮАР, Израиль, Оман. Из регионов России информация поступила главным образом из тех регионов, в которых активно работают орнитологи и имеются команды Аюбителей птиц и фотограсов-анималистов, - из Ярославской, Ульяновской, Псковской областей, Республики Татарстан.

За отчётный период поставлен рекорА по Аальности перемешения птиц, помеченных в рамках программы Российской сети изучения и охраны пернатых хищ-

\footnotetext{
142 http://217.112.43.140/report/4136

143 http://rrrcn.ru/forum/viewtopic.php?f=4\& $t=259 \&$ start $=60 \# p 2740$

144 http://217.112.43.140/report/4309
}

$\begin{array}{ll}145 & \text { http://217.112.43.140/report/4267 } \\ & 146 \\ \text { http://rrrcn.ru/forum/viewtopic.php?f=4\& } t=294 \# p 2874\end{array}$ 


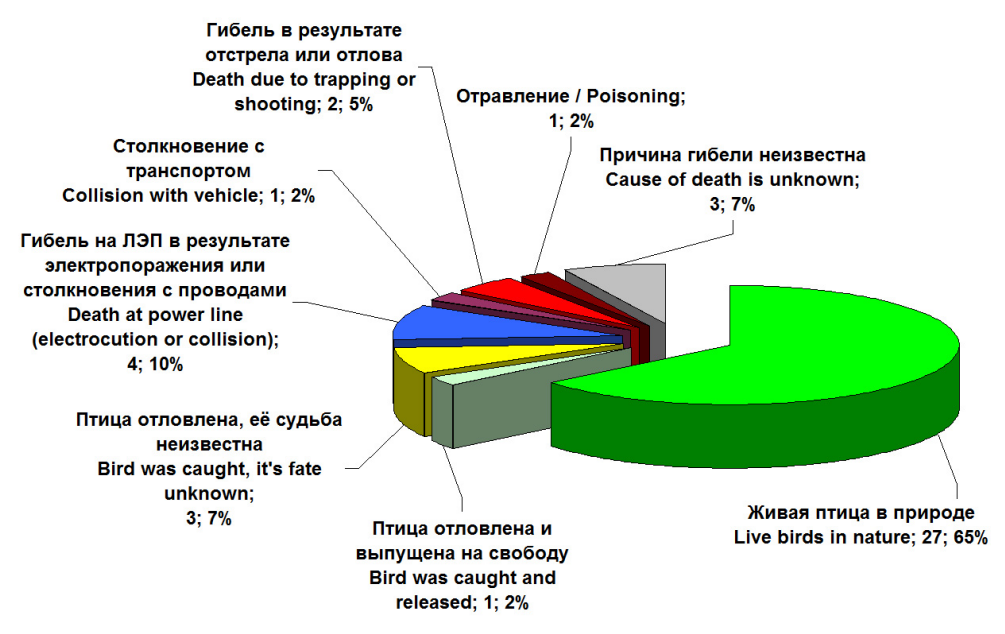

Рис. 12. Причины возвратов.

Fig. 12. Causes of recoveries.

ников. Рекордсменами стами 2 скопы, окольцованные Мирославом Бабушкиным в Ярославской (Аарвинский заповедник) и Вологодской областях. В обоих случаях это были наблюдения живых птиц в природе на дистанциях от места кольцевания 8949,5 км (в Мозамбике) и 10553 км (в ЮАР).

Получены первые регистрации орловмогильников на зимовке в Омане, причём 2-х птиц из одной гнезАовой группировки в Татарстане. Регистрации орлов-могильников, являюшихся млаАшими в выводках из 3-х птенцов, ешё раз показывают, что при хорошей кормовой ситуации, пары орлов способны успешно выкармливать такие большие выводки, вопреки распространённым стереотипам о выживаемости у орлов только старших птенцов.

Получены дополнительные данные о повторных наблюдениях птиц в местах зимовок. Так три орлана-белохвоста, родившиеся на территории Татарстана, были сфотографированы на зимнем скоплении в Ульяновской области. Ава из них отметились второй гоА подряА, а один с перерывом в Ава года.

Стали накапливаться сведения о наблюАении окольцованных птиц вблизи мест своего рождения, что в последуюшем позволит провести анализ фрилопатрии. К примеру, за гнездовой сезон 2015 г. в Татарстане была встречена только 1 окольцованная птица из 45 молодых птиц, мапы которых удалось рассмотреть Аистанционно. Всего в Республике Татарстан с 2012 по 2015 гг. было окольцовано 139 особей орланов. Аоля окольцованных молодых в татарской популяции приближается к 22,86-25,74 \%, исходя из оценки числа птенцов, рожАённых в республике за эти годы (540-608 особей). Поэтому Аоля возвратившихся в популяцию птиц с кольцами может составлять до четверти от численности молодых в возрасте $\Delta$ о 5 лет, однако наблюдаемая филопатрия составила всего 2,22 \% (но реальная может быть выше). Скорее всего, в летнее время на террито-

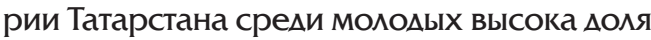
птиц, родившихся за пределами бассейна Средней Волги. В свою очередь в это же время молодые орланы, родившиеся на территории Татарстана, могут обитать на мругих реках, например, на $\Delta$ непре или на $\Delta$ ону, так как схемы предылуших возвратов, указывают на это (Карякин и $ы р$. 2015).

Стоит отметить также, что при близких объёмах кольцевания орланов-белохвостов в Аарвинском заповеднике, доля возвратов птиц в натальную область здесь выше как минимум в 3 раза за аналогичный период. Возможно в верхневолжской популяции ниже отхоА молодых птиц по разным антропогенным причинам, или же ниже уровень послегнездового рассеивания птиц, не возврашаюшихся к местам гнездования в следуюшие годы и оседаюших на Аругих территориях. Возможно, что высокий уровень натальных возвратов в Аарвинском заповеднике связан с использованием фотоловушек, так как только визуальное наблюдение априори даёт более низкие результаты в плане регистрации птиц с кольцами. В целом же, мля полноценного сравнения силопатрии орланов в верхневолжском и средневолжском регионах объективно не хватает Аанных.

За отчётный период получена Аополнительная инсормация по нескольким важным вопросам (Карякин и мр., 2015):

1) причины гибели и травмирования птиц, т.е. их уязвимости на путях миграции;

2) направления и расстояния миграций, места зимовок и остановок на пути;

3) продолжительность жизни, как минимум, $А$ даты встречи, а также уязвимая возрастная группа;

4) зависимость причин смерти или травмирования от направления и дистанции миграции.

Из 38 идентисицированных птиц, 19 попали в руки человека по различным обстоятельствам. Гибель от электротока на птицеопасных АЭП отмечена мия скопы (возраст 3 гола) в Псковской области, мля слётка орла-могильника в Татарстане и мля птицы в возрасте 1,5 лет в Узбекистане (птица успешно пережила 2 зимовки и погибла на начацьном этапе второй весенней 
миграции). Аругой орёл-могильник погиб в результате столкновения с проводами воздушной минии электропередачи в Аһтайском крае, вернувшись в натальную область после успешной зимовки.

Также появилась новая тема мия обсуждения - это проблема отлова птиц на миграционных путях и местах зимовок с коммерческой целью. Так были отловлены скопа в Камеруне (в результате птица погибла), степной орёл в Пакистане, сапсаны в Ираке и Ливии. В последнем случае по сообшению респондента птица была проАана перекупшику соколов из Египта за 9 тыс. Аоммаров США.

Уже Аалеко не первая информация о гибели орлов-могильников из Татарстана на миграциях и местах зимовок показывает, что значительная часть молодых орлов не вернётся к местам своего рожления. Помимо гибели от поражения электротоком

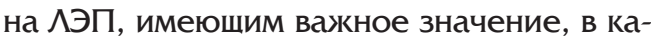

честве прямого мимитируюшего численность фактора (табл. 4, рис. 12), играют роль и такие, как отравление и отстрел.

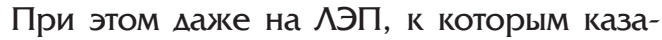
лось бы легче ацаптироваться, чем к отравлению, гибнут не только молодые птицы, но и полувзросые, успешно пережившие несколько сезонов и совершившие Аальние миграции.

Хищные птицы нередко погибают от столкновения с автотранспортом. Вероятно, это связано с охотой на грызунов, часто устраивающих свои колонии на обочинах Аорог. В этот отчётный период получено сообщение о гибели окольцованного слётка степного орла, погибшего на автодороге недалеко от своего гнезда в Оренбургской области.

Особо необходимо отметить сиучаи травмированных птиц и их гибели в результате естественных межвидовых отношений. Так в Оренбургской области выявлен случай по-

Табл. 4. Причины возвратов.

Table 4. Causes of recoveries.

\begin{tabular}{|c|c|c|c|c|c|c|c|c|c|c|c|c|}
\hline \multirow[b]{2}{*}{$\begin{array}{l}\text { Вих } \\
\text { Species }\end{array}$} & \multicolumn{5}{|c|}{ Живая птица / Live birds } & \multicolumn{6}{|c|}{ Мёртвая птица / Dead bird } & \multirow[b]{2}{*}{$\begin{array}{r}\text { Bcero } \\
\text { Total } \\
\end{array}$} \\
\hline & 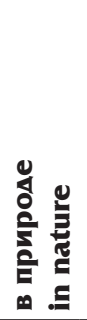 & 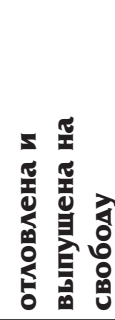 & 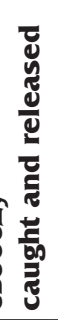 & 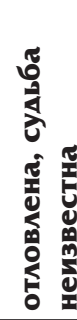 & 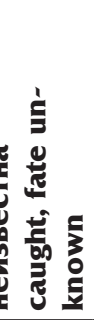 & 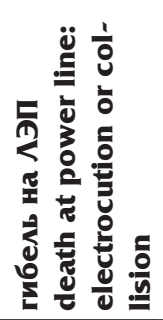 & 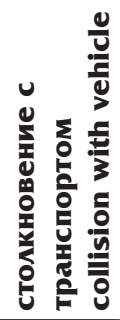 & 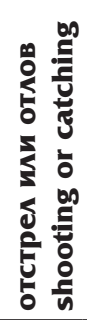 & 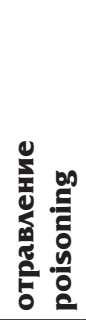 & 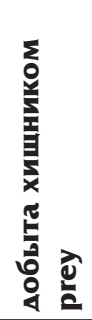 & 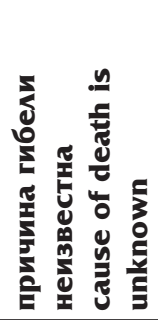 & \\
\hline $\begin{array}{l}\text { Скопа } \\
\text { Pandion haliae- } \\
\text { tus }\end{array}$ & 8 & & & & & 1 & & 1 & & & & 10 \\
\hline $\begin{array}{l}\text { Орлан- } \\
\text { белохвост } \\
\text { Haliaeetus albi- } \\
\text { cilla }\end{array}$ & 16 & & & & & & & & & & 2 & 18 \\
\hline $\begin{array}{l}\text { Oрёл-могильник } \\
\text { Aquila heliaca }\end{array}$ & 1 & & 1 & & & 3 & & & 1 & & & 6 \\
\hline $\begin{array}{l}\text { Opёл степной } \\
\text { Aquila nipalensis }\end{array}$ & & & & & 1 & & 1 & & & $1^{*}$ & 1 & 4 \\
\hline $\begin{array}{l}\text { Большой } \\
\text { подорлик } \\
\text { Aquila clanga }\end{array}$ & 2 & & & & & & & & & & & 2 \\
\hline $\begin{array}{l}\text { Курганник } \\
\text { Buteo rufinus }\end{array}$ & & & & & & & & & & 1 & & 1 \\
\hline $\begin{array}{l}\text { Сапсан } \\
\text { Falco peregrinus }\end{array}$ & & & & & 2 & & & 1 ** & & 2 & & 5 \\
\hline BCEIO / TOTAL & 27 & & $\mathbf{1}$ & & 3 & 4 & $\mathbf{1}$ & $\mathbf{2}$ & $\mathbf{1}$ & 4 & 3 & 46 \\
\hline
\end{tabular}

Примечание / Note:

* - Птенец степного орла был подран четвероногим хищником, реабилитирован, но возврату в природу не подлежит / Nestling of the Steppe Eagle was injured by dog or fox, rehabilitated, but it's return in nature is impossible

** - Несмотря на то, что респондент сообщил о столкновении, более вероятная причина гибели птицы - её убийство голубеводами / Despite the fact that it was reported about collision, more likely cause of death was killing by the breeder pigeons 
лучения поврежцений уже окольцованного птенца степного орла четвероногим хишником на гнезде, расположенном на земле. Выявлен случай гибели окольцованных птенцов сапсана на Ураме в Южно-Ураиьском заповеднике в результате напацения на гнездо филина. Курганник получил повреждения и впоследствии погиб в результате напаления на него орла в Сирии.

Анамиз различных негативных фракторов, влияюших на хишных птиц, не является целью данного обзора, тем не менее, эти данные важны мля тех, кто занимается изучением и охраной хишных птиц в регионах. Аанные сведения дают понимание уровня выживаемости птиц и позволяют критически подходить к оценке негативных факторов в целом, влияюших на популяции, а не только уповать на нарушения естественной среды обитания в местах гнездования.

\section{Благодарности}

Мы благодарим всех участников программы кольцевания, в особенности коорАинаторов по видам и наиболее активных участников - Вамерия Алексеева, Романа Бахтина, Эльвиру Николенко, Галину Пи^югину, Александру Хиопотову и Михаила Шершнева, Амитрия Штоля, Елену Шнаймер, эстонских комег, участвуюших в проекте на Северо-Запале России, особенно Гуннара Сейна (Gunnar Sein), Михкеля Тийдо (Mihkel Tiido) и Урмаса Селиса (Urmas Selis), координаторов европейских и региональных программ, особенно Бьёрна Хеландера (Bjurn Helander), Пертти Саурола (Pertti Saurola), Гжегоша Мациоровского (Grzegorz Maciorowski), Вамерия Аомбровского и Влацимира Ивановского, а также респондентов и фотографов, сообщивших информацию о встречах птиц с кольцами: Алана Крабтри (Alan Crabtree), Айгарса Камьванса (Aigars Kalvans), Анмре Янковского (Andre Jankowski) и Фриде Милисию (Frida Milice), Одилона Геанджима (Odilon Gheahnjim), Роджера Кивена (Roger Kiven Wikinyuy), Михаэля Бэкхэма (Michael Buckham), Ори Алмога (Ori Almog), Аениса Кителя, Сергея Плыткевича, Андрея Власова, Рахика Кутушева, Максима Королькова, Вацима Вацекова, Михаила Тимосеева, Андрея Москвичёва, Айлара Муртазина, Аюбовь Маловичко, Ашутоша Паи (Ashutosh Pai), Виктора Реджинальда (Reginald Victor), Майка МакГради (Mike McGrady), Салема Аиь Машани (Salem A Al Mashani), Аениса Чои, Ашгара Мохаммахи (Asghar Mohammadi), Kopoca
Рбие (Koros Rbiee), Немера Аиаси (Nemer Alasi), Вячеслава Фёцорова, Аиьбару Бинозмана (Albara Binothman) и Ирама Солника (Irad Solnik).

\section{Митература}

Бекмансуров Р.X. Орлан, окольцованный в Татарии в 2011 г., встречен под Киевом. Российская сеть изучения и охраны пернатых хишников, 2012. [Bekmansurov R.H. WhiteTailed Eagle ringed in Tatarstan in 2011 has been recorded near Kiev. - Russian Raptor Research and Conservation Network, 2012]. URL: http:// rrrcn.ru/ru/archives/9340 Аата обрашения: 10.10.2016.

Бекмансуров Р.Х., Аюпов А.С., Карякин И.В., Костин Е.С. Результаты мониторинга гнездовых группировок орлана-белохвоста на некоторых особо охраняемых и прилегаюших к ним природных территориях в Республике Татарстан в 2012 году, Россия. - Пернатые хишники и их охрана. 2012. № 25. C. 79-96. [Bekmansurov R.H., Ayupov A.S., Karyakin I.V., Kostin E.S. Results of the Monitoring of the White-Tailed Eagle Populations in Some Protected Areas and Adjacent Territories in the Republic of Tatarstan in 2012, Russia. - Raptors Conservation. 2012. 25: 79-96]. URL: http://rrrcn.ru/ru/archives/19107 Аата обрашения: 11.10.2016.

Карякин И.В., Бекмансуров Р.Х., Бабушкин М.В., Важов С.В., Бахтин Р.Ф., Николенко Э.Г., Шнайцер Е.П., Пименов В.Н. Результаты работы Центра кольцевания хишных птиц Российской сети изучения и охраны пернатых хишников в 2014 году. - Пернатые хищники и их охрана. 2015. № 30. C. 31-61. DOI: 10.19074/1814-86542015-30-31-61 [Karyakin I.V., Bekmansurov R.H., Babushkin M.V., Vazhov S.V., Bachtin R.F., Nikolenko E.G., Shnayder E.P., Pimenov V.N. Results of work of the Raptor Ringing Center of the Russian Raptor Research and Conservation Network in 2014. - Raptors Conservation. 2015. 30: 31-61. DOI: $\quad 10.19074 / 1814-8654-2015-30-31-61]$. URL: http://rrrcn.ru/ru/archives/25960 Аата обрашения: 10.10.2016.

Карякин И.В., Зиневич А.С., Шепетов А.М., Сорокина С.Ю. Популяционная структура ареала степного орла и предварительные данные по генетическому разнообразию его популяций и статусу подвицов. - Пернатые хишники и их охрана. 2016. № 32. С. 67-88. DOI: 10.19074/18148654-2016-32-67-88 [Karyakin I.V., Zinevich L.S., Schepetov D.M., Sorokina S.Yu. Population Structure of the Steppe Eagle Range and Preliminary Data on the Population Genetic Diversity and Status of Subspecies. - Raptors Conservation. 2016. 32: 67-88. DOI: 10.19074/1814-86542016-32-67-88]. URL: http://rrrcn.ru/ru/archives/26941 Аата обрашения: 11.10.2016.

Sokolov A., Sokolov V., Dixon A. Return to the Wild: Migratory Peregrine Falcons Breeding in Arctic Eurasia Following Their Use in Arabic Falconry. - J. Raptor Res. 2016. 50 (1): 103-108. 